\title{
Exports and Capacity Constraints: Evidence for Several Euro Area Countries
}

\author{
Ansgar Belke \\ Anne Oeking \\ Ralph Setzer
}
CESIFO WORKING PAPER NO. 5455
CATEgory 6: FisCal POLICY, MaCROECONOMICS AND GROWTH
JULY 2015

Presented at CESifo - Delphi Conference on Current Account Adjustments, May 2015

An electronic version of the paper may be downloaded

- from the SSRN website: Www.SSRN.com

- from the RePEc website: $\quad$ www.RePEc.org

- from the CESifo website: $\quad$ www.CESifo-group.org/wp 


\title{
Exports and Capacity Constraints: Evidence for Several Euro Area Countries
}

\begin{abstract}
We argue that, under certain conditions, firms consider exports as a substitute for domestic demand. Our econometric model for six euro area countries suggests domestic demand and capacity constraints as additional variables for export equations. We apply the exponential and logistic variant of a smooth transition regression model and find that domestic demand developments are relevant for short-run export dynamics particularly during more extreme stages of the business cycle. A substitutive relationship between domestic and foreign sales can most clearly be found for Spain, Portugal and Italy, providing evidence of the importance of sunk costs and hysteresis in international trade.
\end{abstract}

JEL-Code: F140, C220, C500, C510, F100.

Keywords: domestic demand pressure, error-correction models, hysteresis, modelling techniques, smooth transition models, exports, sunk costs.

Ansgar Belke
University of Duisburg-Essen
Universitätsstr. 12
Germany-45117 Essen
ansgar.belke@uni-due.de
Anne Oeking*
University of Duisburg-Essen
Universitätsstr. 12
Germany-45117 Essen
anne.oeking@uni-due.de

*corresponding author

July 2015

The views expressed are those of the authors and do not necessarily reflect those of their institutions. - The authors would like to thank Joscha Beckmann, Stéphane Dees, Philippe de Rougemont, Frauke Skudelny, Florian Verheyen, participants in the IMF research department's brown bag seminar, the ECB's DED seminar and the CESifo-Delphi conference on "Current Account Adjustments" for valuable comments and suggestions. We thank Christian Buelens for the provision of data on value-added exports. 


\section{Introduction}

A number of euro area countries which recorded large current account deficits in the pre-crisis period have seen a significant correction of their external imbalances, in particular the trade balance, over recent years. Falling imports have been an important part of this correction due to low domestic demand. However, at the same time, exports and export market shares have been continuously increasing in most of these countries since 2009. Shrinking unit labour costs and falling real effective exchange rates are able to explain only part of the gains in export market shares. Christodoulopoulou and Tkacevs (2014) find that only $60-70 \%$ of variation in exports can be explained by standard export equations. It thus seems likely that non-price related factors have been important in explaining export performance. The residuals from a standard approach to model exports are potentially consistent with the parallel dramatic fall of domestic demand. A possible relationship between domestic demand and exports could be particularly important in the current economic situation of substantial macroeconomic adjustment needs and very low domestic demand.

The relation between domestic demand and exports is not straightforward and could be either negative (substitutive) or positive (complementary). A recent survey of literature on this topic is presented in Esteves and Rua (2013). Theoretical reasons for a positive link between domestic demand and exports may be due to increased efficiency from learning by doing effects (Belke et al. (2013)) or due to liquidity generated by cash flow from exports which can help overcome liquidity constraints for domestic operations (Berman et al. (2011)). Theory has identified a negative relationship between domestic demand and exports mostly at the firm level. Several studies have been concerned with the effects of domestic demand pressure on the inclination and capacity to export. These studies are not numerous, but go back several decades. ${ }^{2}$ The main argument is that - in the short-run-exporting firms face capacity constraints or increasing marginal costs and thus have to substitute sales between their domestic and foreign markets. An increase in demand for exports cannot be satisfied in the short-run as long as capacity is highly utilised and most of production is sold on the domestic market. Conversely, with low domestic demand, for instance during a domestic recession, firms will be able to shift more resources to export activities; to compensate for the decline in domestic sales, firms will increase their efforts to export. Besides pull factors (e.g. foreign demand), export performance can thus also be determined by push factors (such as low capacity utilisation). Besides the studies mentioned above, more recent empirical literature (e.g. Ilmakunnas and Nurmi (2007), Máñez et al. (2008), Berman et al. (2011), Blum et al. (2011), Vannoorenberghe (2012) or Ahn and McQuoid (2013)) generally identifies a significant negative effect of domestic demand pressure on exports for several countries, among them the United Kingdom, the United States, Germany, Spain, Israel, Turkey, Morocco and India.

\footnotetext{
${ }^{2}$ Examples are Ball et al. (1966), Smyth (1968), Artus (1970, 1973), Dunlevy (1980), Zilberfarb (1980), Faini (1994) and Sharma (2003).
} 
The main lesson from the literature is that any exercise of modelling export performance should take into account not only the factors driving external demand (and thus impact export activity from the demand side), but also those influencing domestic demand (which affect export activity mostly through the supply side). Moreover, the studies underline the necessity of clearly differentiating between the short and the long-run. One potential limitation of the previous literature is that the complementarity versus substitutability property of domestic demand and exports has often been analysed in a linear framework. The relationship between domestic demand and export performance may however vary with economic conditions and thus be of a non-linear nature.

Assuming a substitutive relationship between domestic demand and exports, following a domestic demand shock, firms will try to shift sales between the two markets. However, entering the export market or shifting more sales towards it usually implies sunk costs. These are costs firms need to pay that are irreversible ex post (Baldwin and Krugman (1989)) and the significance of this knowledge diminishes rapidly after leaving the export market (Belke et al. (2013)). We can distinguish two cases. First, with a negative domestic demand shock and sunk costs for entering or shifting to the export market, firms will therefore be reluctant to pay these costs as long as capacity is still relatively highly utilised. Once capacity utilisation falls below a certain threshold, firms might be more willing to pay sunk investment costs as these costs and the effort of selling in the foreign market might be lower than the cost of running excess capacity. ${ }^{3}$ Exports in this case can be considered as "survival-driven". Second, following a positive domestic demand shock, firms might not be able to serve both domestic and foreign markets due to highly utilised capacities. If they prefer producing for the domestic market, firms would consider shifting sales to that market once a certain high capacity utilisation threshold has been crossed. With sunk costs, leaving the export market or shifting sales away from it implies that these costs would have to be paid again upon trying to re-enter the export market or reshifting sales towards it in the future.

Overall, these arguments suggest that only if certain low or high capacity utilisation thresholds have been crossed, firms will change their export behaviour. Only if a domestic demand shock is accompanied by extreme changes in capacity utilisation will firms shift their sales to another market. As long as capacity is utilised to a more normal degree and operates within these lower and upper thresholds, firms are working in a "band of inaction" where sunk costs hinder firms from changing their export behaviour even though capacities might exist for those firms that are not yet very active in foreign markets. ${ }^{4}$ This also implies that once capacity utilisation thresholds have been crossed on either end and firms have shifted sales among

\footnotetext{
${ }^{3}$ Alternatively, some firms might be constrained by technical limitations that allow production at a certain capacity utilisation rate only; facing a certain low capacity utilisation threshold they might face the decision to either not produce at all or shift their production to serving foreign markets.

${ }^{4}$ In the European case and the countries under consideration, potential for shifting production to foreign markets seems to exist. As an example, Esteves and Rua (2013) specify that in 2010, only one third of Portuguese manufacturing firms was exporting and for them the exports to sales ratio was on average around 30 per cent.
} 
markets, they will be reluctant to shift again once capacity returns back to more normal levels. There is thus strong persistence in export behaviour which can be traced to the theory of hysteresis. Export hysteresis is the tendency of a temporary change in export behaviour to become permanent. It is particularly important in the current weak economic situation of several euro area member states; firms increase efforts to shift sales to the export market given weak domestic demand and this might not be a cyclical change but rather a persistent improvement as firms will often decide to stay in the foreign market even once domestic demand picks up again as they are trying to avoid repaying sunk costs.

Our paper builds on this sunk-cost hysteresis model and explicitly tests for a short-run non-linear relationship between domestic demand and exports from a macroeconomic perspective. A particular asymmetric effect was already considered in Esteves and Rua (2013) for the case of Portugal. Belke et al. (2014) consider the relation of domestic demand and export of goods in several euro area countries. Our analysis goes beyond these studies by focusing on six euro area countries with significant current account deficits in the pre-crisis period (Spain, Portugal, Italy, France, Ireland and Greece), focusing on the export of both goods and services. Following Belke et al. (2014), we implement a smooth transition regression model such that we can specify aggregated non-linearities with a high degree of flexibility. We argue that the strength of the relation between domestic demand and exports depends on capacity constraints and more generally the business cycle. Besides the possibility that substitutability will increase after reaching either the upper or lower threshold (i.e. giving rise to symmetry around the band of inaction), we also allow for the possibility that exports react sharper in a recession than during an economic expansion (giving rise to asymmetry around the band of inaction). This is achieved by relying on either an exponential or logistic variant of smooth transition specification. The aggregation at the macro level allows us to draw results on net effects of capacity utilisation on the economies as a whole. This is of special importance in the discussion of macroeconomic adjustment and the reduction of current account imbalances in the euro area.

The paper proceeds as follows. Taking the simple sunk cost-based hysteresis model as a starting point, we carry out some pre-testing in terms of unit roots and cointegration in section 2. Based on the cointegration results, we set up an error-correction export equation and incorporate non-linearities as suggested by our theoretical considerations. These smooth transition regression models (STR), including several robustness tests, are estimated in section 3 . Section 4 concludes.

\section{Empirical strategy}

\section{Data}

Our data stems from different sources (cf. table A1): Data on real exports $\left(x_{t}\right)$ and real domestic demand $\left(d d_{t}\right)$ comes from the national statistical offices (either obtained from Eurostat or Oxford Economics). Value added exports $\left(x_{t}^{v a}\right)$ have been constructed by data from the World Input-Output Database (wiod.org); the 
annual data were converted to quarterly data by applying cubic spline interpolation. The real effective exchange rate has been obtained from Eurostat and is an index deflated by consumer price indices with a country's 15 main trading partners $\left(r_{t}\right)$. Alternatively, the same source provides an index deflated by unit labour costs with a country's 24 main trading partners $\left(r_{t}^{U L C}\right)$. Data on foreign demand $\left(y_{t}^{*}\right)$ from the ECB is based on trade-weighted imports for a country's 15 main trading partners. Capacity utilisation data in the manufacturing industry $\left(z_{t}\right)$ comes from the Business and Consumer Surveys by the European Commission, available from Eurostat or Insee in the case of France. For Ireland, data on capacity utilisation is not available. Instead, we use the output gap (interpolated data from AMECO). The final data set is quarterly and mostly available from 1980:Q1 to 2012:Q4.

\section{Non-stationarity and cointegration tests}

Standard empirical models of international trade predict that the volume of exports of a country is in the long-run a function of its foreign demand and its relative price level regarding its main trading partners. As a first step, we therefore estimate such a long-run export equation. In a second step below, we estimate an error-correction model which focuses on the short-run effects by applying a non-linear framework. Throughout, we take each series in (natural) logarithms. Before estimating, we apply an augmented DickeyFuller test (ADF-test) to check whether the variables in our model are non-stationary. Here, we specify the auxiliary regressions to include an intercept for the real effective exchange rate series and an intercept plus a time trend for all other series. To support these results, we also use the LM unit root test procedure as developed by Lee and Strazicich (2003). This test accounts for possible structural breaks in the series, and we perform it at the series' levels to test for the correctness of the above ADF test results. ${ }^{5}$ Results for both tests are found in table $\mathrm{A} 2$ and let us conclude that the series are all non-stationary.

Next, we apply the Engle-Granger approach to test for cointegration given our non-stationary variables and estimate the following long-run equilibrium relationship:

$$
x_{t}=b_{1}+b_{2} y_{t}^{*}+b_{3} r_{t}+b_{4} d+b_{5} d \cdot y_{t}^{*}+b_{6} d \cdot r_{t}+e_{t}
$$

where $x_{t}$ is the log of exports, $y_{t}^{*}$ the log of foreign demand, $r_{t}$ the log of the real effective exchange rate and $d$ a dummy and its respective interaction terms to capture a structural break. We set $d=1$ if $t \geq$ break point, otherwise $d=0$. We identify the break for each country by a multiple structural change analysis following Bai and Perron (2003) and by a Gregory-Hansen cointegration test (Gregory and Hansen (1996a), (1996b)). ${ }^{6}$ The break points we identify are all found in the time period between the European Exchange Rate Mechanism (ERM) crisis of 1992/1993 and the introduction of the euro in 1999.

\footnotetext{
${ }^{5}$ We apply the LM test by Lee and Strazicich to each series with one break and two breaks. The breaks each represent a shift in levels and is determined by an endogenously set date.

${ }^{6}$ We allow a maximum number of two breaks for the Bai and Perron test, but due to the relatively short time series we end up focusing on one break for estimation of the cointegration relation. The Gregory Hansen test allows for one
} 
Table 1: Engle-Granger Test for Cointegration

\begin{tabular}{lccccc} 
Country & Lags & Test Statistic & Critical value 1\% & Critical value 5\% & Critical value 10\% \\
\hline Spain & 0 & $-5.88026^{* * *}$ & -5.44302 & -4.83614 & -4.52609 \\
Portugal & 2 & $-4.45270^{*}$ & -5.13257 & -4.52552 & -4.21549 \\
Italy & 2 & $-4.63834^{* *}$ & -5.13676 & -4.52809 & -4.21747 \\
France & 3 & $-5.50043^{* *}$ & -5.44784 & -4.83923 & -4.52847 \\
Ireland & 1 & $4.67103^{* *}$ & -5.13121 & -4.52468 & -4.21486 \\
Greece & 0 & $-5.75130^{* * *}$ & -5.44302 & -4.83614 & -4.52609
\end{tabular}

Tests the null hypothesis that there is no cointegration (i.e. that the residual series has a unit root). The (approximate) critical values for the t-test are from MacKinnon (1991) for the respective number of variables. $* * * / * * *$ statistical significance at the $10 \% / 5 \% / 1 \%$ level.

We estimate the long-run equilibrium (1) by fully modified least squares (FMOLS) and perform an EngleGranger test for cointegration (see table 1 for test results with the respective critical values from MacKinnon (1991)). For each country, we find that the error terms are stationary $\left(\widehat{e_{t}} \sim I(0)\right)$ and therefore conclude that there is a cointegration relationship between the variables. The results from the FMOLS estimation can be found in table 2.

Our results largely match those of other studies; both in terms of sign and size of the coefficients (cf. e.g. European Commission (2011)). We do not give a more detailed analysis as our main focus is on the short-run relation and slightly different long-run specifications did not change the following results in a noteworthy way. $^{7}$

Table 2: Long-Run Relationship

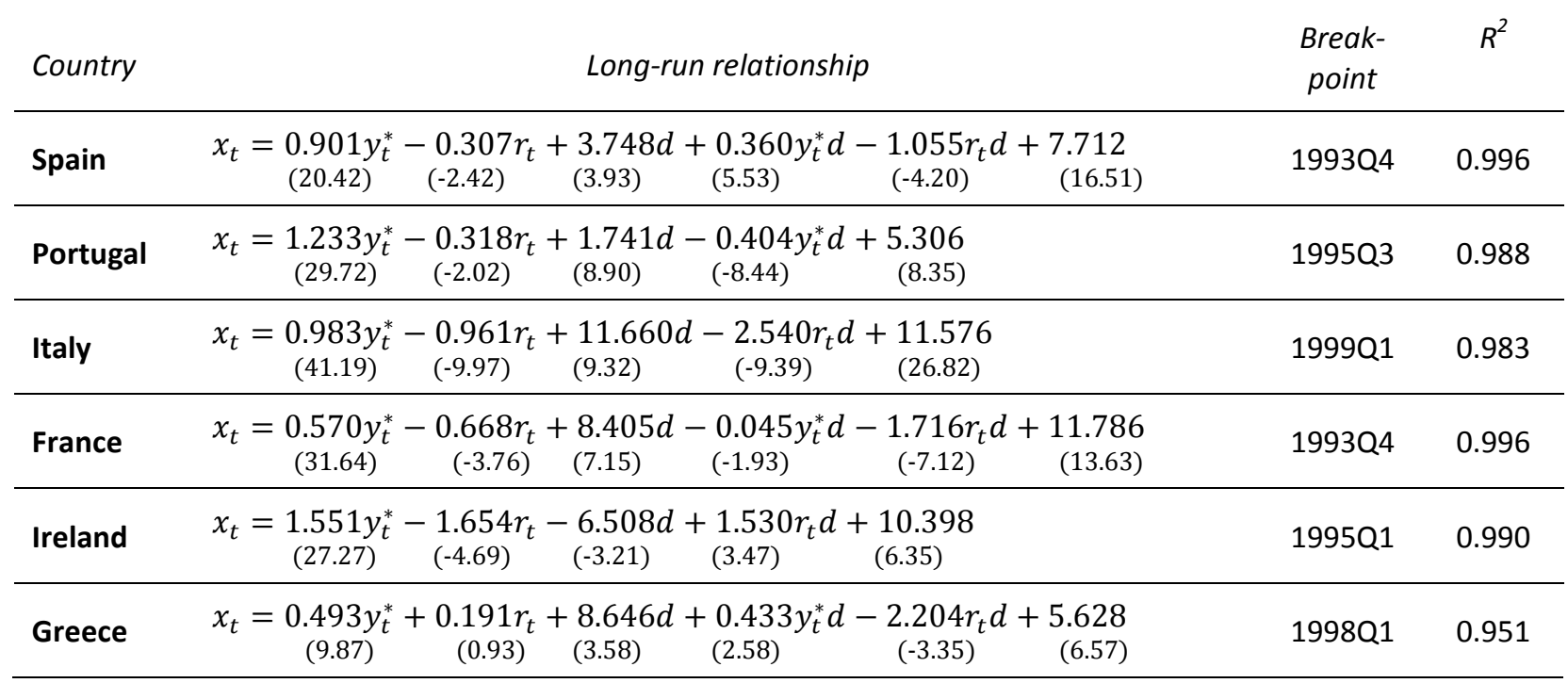

Estimated by FMOLS. t-values in parentheses. The structural break dummy $\mathrm{d}$ is defined as $d=1$ if $t \geq$ break point, otherwise $d=0$.

break in the cointegration regression. More breaks would have led to events such as the global crisis in 2008 to be considered as another break.

${ }^{7}$ As robustness checks, we also included additional variables in the long-run relation, e.g. trade openness, or restricted the coefficient for foreign demand to unity. Other non-price competitiveness variables could also have an influence on exports. As Esteves and Rua (2013) point out, the long-run results need to be interpreted with caution, as further structural breaks or these potential omitted variables could have an influence on the outcomes. Since our focus is on the short-run results and the short-run non-linear estimation appear to be relatively insensitive to slightly different long-run specifications, we do not report these results here. 


\section{Empirical model}

As explained above, we apply a non-linear framework to capture any short-run non-linear impact in the relation between domestic demand and exports regarding the state of the economy. We consider each country's economic condition by looking at deviations of its capacity utilisation from its mean. Looking at short-run adjustments and in particular at the short-run relation between exports and domestic demand, we take into account the long-run equilibrium estimated above. For this purpose, we apply an error-correction model. As already mentioned in the introduction, we take into account the possibility of a non-linear adjustment process to a linear long-run equilibrium relationship depending on the state of the economy. Based on an economy's export performance where individual firm level decisions are aggregated, it may not seem adequate to assume that this threshold is a sudden and abrupt change which is identical for all firms and which is commonly known; the smooth-transition regression (STR) model thus allows for gradual regime change when the timing of the regime switch varies on an aggregated level. We will therefore estimate the following error-correction model with non-linear short-run adjustment in STR form:

$$
\begin{gathered}
\Delta x_{t}=\left[\alpha_{1}+\sum_{i=0}^{n-1} \beta_{1 i} \Delta d d_{t-i}+\sum_{i=0}^{n-1} \theta_{1 i} \Delta y_{t-i}^{*}+\sum_{i=0}^{n-1} \mu_{1 i} \Delta r_{t-i}+\sum_{i=1}^{n-1} \eta_{1 i} \Delta x_{t-i}+\delta_{1} \hat{\varepsilon}_{t-1}\right]+ \\
{\left[\alpha_{2}+\sum_{i=0}^{n-1} \beta_{2 i} \Delta d d_{t-i}+\sum_{i=0}^{n-1} \theta_{2 i} \Delta y_{t-i}^{*}+\sum_{i=0}^{n-1} \mu_{2 i} \Delta r_{t-i}+\sum_{i=1}^{n-1} \eta_{2 i} \Delta x_{t-i}+\delta_{2} \hat{\varepsilon}_{t-1}\right] F\left(z_{t-j}, \gamma, c\right)+u_{t}}
\end{gathered}
$$

$$
\hat{\varepsilon}_{t-1}=x_{t-1}-\hat{b}_{1}-\hat{b}_{2} y_{t-1}^{*}-\hat{b}_{3} r_{t-1}-\hat{b}_{4} d-\hat{b}_{5} d \cdot y_{t-1}^{*}-\hat{b}_{6} d \cdot r_{t-1}
$$

such that $\Delta x_{t}$ is a function of lagged equilibrium errors (the error-correction term $\delta_{1} \hat{\varepsilon}_{t-1}$, where $\hat{\varepsilon}_{t}$ refers to the error term of the long-run cointegration relation between $x_{t}, y_{t}^{*}$ and $r_{t}$ determined in the previous step), changes in domestic demand $d d_{t}$, foreign demand $y_{t}^{*}$, the real effective exchange rate $r_{t}$ and past changes of its own value. The parameter $\delta$ is referred to as the adjustment effect which gives information about the speed of adjustment when there is disequilibrium and parameters $\alpha, \beta, \theta, \mu, \eta$ are the short-run effects. Our main parameter of interest is $\beta$, the short-run elasticity of exports to a change in domestic demand.

The main difference between our short and long-run specification is the inclusion of the domestic demand variable. Based on the theoretical arguments given in the introduction above, domestic demand should enter our estimations in the short-run only. ${ }^{8}$ In contrast to the long-run estimation, we do not include a structural break in the short-run estimations of equation (2) because this specification already includes the smooth transition non-linearities. Furthermore, a break in the long-run relation does not imply that shortrun dynamics change as well; by excluding these breaks we are also able to reduce our model's complexity. The first set of brackets in equation (2) is a standard linear error-correction model. Non-linearity is introduced via the second set of brackets which includes the same regressors, but is multiplied with the transition function $F\left(z_{t-j}, \gamma, c\right)$. The transition function in a STR model is a smooth, continuous and bounded function between 0 and 1. We consider two popular forms of smooth transition models based on

\footnotetext{
${ }^{8}$ As a robustness test, we also included domestic demand in the above long-run cointegration relation. Its coefficient did neither turn out to be statistically significant nor did it help to constitute a better long-run relation.
} 
the transition function. These are the logistic STR model (LSTR) and exponential STR model (ESTR). The LSTR model uses a logistic transition function of the following form:

$$
F\left(z_{t-j}, \gamma, c\right)=\left[1+\exp \left(-\frac{\gamma}{\sigma_{z}}\left(z_{t-j}-c\right)\right)\right]^{-1} \text { with } \gamma>0
$$

with the transition variable $z$ distinguishing different regimes in our non-linear estimation. In our case $z$ is operationalised by the degree of capacity utilisation to capture business cycle effects (in particular in the manufacturing industry). We look at deviations of $z$ from a threshold value $c$ which we set as the average value of capacity utilisation over our sample time period. ${ }^{9}$ Smoothness parameter $\gamma$ determines strength and speed of the transition and $\sigma_{z}$ is the standard deviation of the transition variable. As the smoothness parameter $\gamma$ depends on the scaling of the transition variable, we follow Teräsvirta (1998) and normalize it by $\sigma_{z}$ in order to be scale-free).

The logistic transition function increases monotonically from 0 to 1 as the value of transition variable $z$ increases. We can therefore distinguish two different regimes in the extreme and a gradual transition between these two: (i) negative deviations of the transition variable from its threshold: $\lim _{z_{t-j} \rightarrow-\infty} F\left(z_{t-j}, \gamma, c\right)=0$, when the model collapses to just the first set of brackets in equation (2), i.e. the linear part, and (ii) positive deviations of the transition variable from its threshold: $\lim _{z_{t-j} \rightarrow+\infty} F\left(z_{t-j}, \gamma, c\right)=1$. The coefficients $\alpha, \beta, \theta, \mu, \eta, \delta$ gradually change between these two extreme values with changing $z_{t-j}$.

In our setting, this implies testing the hypothesis that domestic sales are substituted by foreign sales once capacity utilisation falls below a certain threshold. Further reductions in capacity reduction strengthen the substitution of domestic demand by exports. Note that there is no threshold for the opposite case of high capacity utilisation. In other words, the band of inaction is only constrained on one side (for negative but not for positive deviations of capacity utilisation from its mean).

The ESTR model relies on an exponential transition function of the following functional form:

$$
F\left(z_{t-j}, \gamma, c\right)=1-\exp \left[-\frac{\gamma}{\sigma_{z}}\left(z_{t-j}-c\right)^{2}\right] \text { with } \gamma>0 .
$$

This transition function is symmetric (U-shaped) around $\mathrm{z}_{\mathrm{t}-\mathrm{j}}=\mathrm{c}$ so that the two different regimes to distinguish between are: (i) large deviations of the transition variable from its threshold: $\lim _{\mathrm{z}_{\mathrm{t}-\mathrm{j}} \rightarrow \pm \infty} \mathrm{F}\left(\mathrm{z}_{\mathrm{t}-\mathrm{j}}, \gamma, \mathrm{c}\right)=1$ and (ii) small deviations of the transition variable from its threshold: $\lim _{z_{t}-j \rightarrow c} F\left(z_{t-j}, \gamma, c\right)=0$, i.e. the linear part .

In our case, the ESTR model represents the hypothesis of symmetric hysteresis in exports. Here, both positive and negative deviations of the threshold variable capacity utilisation from its average value $c$ matter. This implies that as long as the deviation of the transitional variable from $c$ is small, there would be

\footnotetext{
${ }^{9}$ As a robustness check, we also apply the same estimations by looking at deviations of $z$ from its mean value. Final results remain similar. Results are available from the authors upon request.
} 
no or only small substitution effects from domestic demand to exports (band of inaction). However, if the capacity utilisation variable is either significantly above or below its average value, we would expect substitution effects.

The main difference between these two forms of non-linear error-correction model refers to different deviations of the transition variable from its threshold value (its mean): the LSTR case distinguishes positive vs. negative deviations and the ESTR model large vs. small deviations from equilibrium. The former will therefore yield asymmetric results around the threshold, and the latter symmetric deviations above or below the threshold.

\section{Empirical results}

\section{Specification tests}

To test for the presence of an STR model, Teräsvirta (1994) developed the following framework which tests both for the presence of non-linear behaviour and for an LSTR vs. ESTR process. The basis for this test is a Taylor series expansion of the STR model in which the transition function is approximated by the following third-order Taylor expansion:

$$
\Delta x_{t}=\varphi_{0}+\varphi_{1} W_{t}+\varphi_{2} W_{t} z_{t-j}+\varphi_{3} W_{t} z_{t-j}^{2}+\varphi_{4} W_{t} z_{t-j}{ }^{3}+\epsilon_{t}
$$

where $\quad W_{t}=\left(\Delta d d_{t}, \Delta d d_{t-1}, \ldots, \Delta d d_{t-p}, \Delta y_{t}^{*}, \ldots, \Delta y_{t-p}^{*}, \Delta r_{t}, \ldots, \Delta r_{t-p}, \Delta x_{t-1}, \ldots, \Delta x_{t-p}, \hat{\varepsilon}_{t-1}\right) \quad$ and $\quad \varphi_{i}=$ $\left(\varphi_{i 1}, \ldots, \varphi_{i q}\right)^{\prime}$ with $q$ equal to the number of regressors (i.e. the number of elements in $\left.W_{t}\right)$. To get a first idea of how many regressors and how many lags of each variable to include in $W_{t}$, we first estimate the linear part of the VECM model with all different combinations of lags (up to $p=4$ ) and choose the number of lags based on the Schwarz information criterion.

Testing for linearity means testing the joint restriction that every non-linear term in this expression is zero against the alternative hypothesis of a STR model. Formally, following (Teräsvirta 1998), this is (i) $H_{0}: \varphi_{i}=0$ for $i=2,3,4$ against the alternative $H_{A}: \varphi_{i} \neq 0$ for at least one of $i=2,3,4$, implying non-linearity due to significant higher order terms. We apply the test for different lag lengths $j$ of the transition variable and select the value of $j$ that results in the smallest $p$-value, as this is believed to provide the best estimate of $j$; when the $\mathrm{p}$-values are the same, we also consider the values of $\bar{R}^{2}$ of the particular regression model. Plausible values for the lag length for quarterly data are here assumed to be $j=1, \ldots, 6{ }^{10}$ Table 3 shows the test results. With the exception of France, the null hypothesis can be clearly rejected for each country and every lag; ${ }^{11}$ non-linear estimations seem to be appropriate.

\footnotetext{
${ }^{10}$ Longer lag lengths (up to $\mathrm{j}=8$ ) were carried out as robustness checks, but turned out to be less suitable.

${ }^{11}$ France is an exception; here, null hypothesis cannot be rejected for higher lag lengths.
} 
Table 3: Teräsvirta test for non-linearity and choice of lag length of transition variable

\begin{tabular}{|c|c|c|c|c|c|c|c|}
\hline & $\begin{array}{c}\text { test } \\
\text { statistic } \\
\text { for } j=1\end{array}$ & $\begin{array}{c}\text { test } \\
\text { statistic } \\
\text { for } j=2\end{array}$ & $\begin{array}{c}\text { test } \\
\text { statistic } \\
\text { for } j=3\end{array}$ & $\begin{array}{c}\text { test } \\
\text { statistic } \\
\text { for } j=4\end{array}$ & $\begin{array}{c}\text { test } \\
\text { statistic } \\
\text { for } j=5\end{array}$ & $\begin{array}{c}\text { test } \\
\text { statistic } \\
\text { for } j=6\end{array}$ & $\begin{array}{c}\text { Proposed lag } \\
\text { length }\end{array}$ \\
\hline Spain & $\begin{array}{c}372.18 \\
(0.000) \\
{[0.58]} \\
\end{array}$ & $\begin{array}{c}178.31 \\
(0.000) \\
{[0.51]} \\
\end{array}$ & $\begin{array}{l}85.41 \\
(0.000) \\
{[0.53]}\end{array}$ & $\begin{array}{c}920.17 \\
(0.000) \\
{[0.60]} \\
\end{array}$ & $\begin{array}{c}118.78 \\
(0.000) \\
{[0.56]} \\
\end{array}$ & $\begin{array}{c}111.00 \\
(0.000) \\
{[0.58]} \\
\end{array}$ & 4 \\
\hline Portugal & $\begin{array}{l}34.50 \\
(0.001) \\
{[0.34]} \\
\end{array}$ & $\begin{array}{c}33.48 \\
(0.001) \\
{[0.38]} \\
\end{array}$ & $\begin{array}{c}108.94 \\
(0.000) \\
{[0.37]} \\
\end{array}$ & $\begin{array}{c}121.89 \\
(0.000) \\
{[0.33]} \\
\end{array}$ & $\begin{array}{c}251.97 \\
(0.000) \\
{[0.41]} \\
\end{array}$ & $\begin{array}{c}1270.97 \\
(0.000) \\
{[0.45]} \\
\end{array}$ & 6 \\
\hline Italy & $\begin{array}{c}105.25 \\
(0.000) \\
{[0.46]} \\
\end{array}$ & $\begin{array}{c}137.53 \\
(0.000) \\
{[0.46]} \\
\end{array}$ & $\begin{array}{l}55.13 \\
(0.000) \\
{[0.42]} \\
\end{array}$ & $\begin{array}{l}79.38 \\
(0.000) \\
{[0.50]} \\
\end{array}$ & $\begin{array}{c}116.32 \\
(0.000) \\
{[0.51]} \\
\end{array}$ & $\begin{array}{c}113.27 \\
(0.000) \\
{[0.59]} \\
\end{array}$ & 6 \\
\hline France & $\begin{array}{c}35.016 \\
(0.002) \\
{[0.39]} \\
\end{array}$ & $\begin{array}{c}23.955 \\
(0.014) \\
{[0.41]} \\
\end{array}$ & $\begin{array}{c}20.509 \\
(0.042) \\
{[0.38]} \\
\end{array}$ & $\begin{array}{c}14.832 \\
(0.192) \\
{[0.39]} \\
\end{array}$ & $\begin{array}{c}15.798 \\
(0.111) \\
{[0.39]} \\
\end{array}$ & $\begin{array}{l}7.532 \\
(0.755) \\
{[0.39]} \\
\end{array}$ & 1 \\
\hline Ireland & $\begin{array}{c}188.90 \\
(0.000) \\
{[0.65]} \\
\end{array}$ & $\begin{array}{c}249.53 \\
(0.000) \\
{[0.64]} \\
\end{array}$ & $\begin{array}{c}182.05 \\
(0.000) \\
{[0.65]}\end{array}$ & $\begin{array}{c}204.51 \\
(0.000) \\
{[0.68]}\end{array}$ & $\begin{array}{c}100.73 \\
(0.000) \\
{[0.64]} \\
\end{array}$ & $\begin{array}{l}89.36 \\
(0.000) \\
{[0.60]} \\
\end{array}$ & 4 \\
\hline Greece & $\begin{array}{c}1764.02 \\
(0.000) \\
{[0.51]}\end{array}$ & $\begin{array}{c}1619.83 \\
(0.000) \\
{[0.58]}\end{array}$ & $\begin{array}{c}146.17 \\
(0.000) \\
{[0.49]} \\
\end{array}$ & $\begin{array}{l}97.69 \\
(0.000) \\
{[0.49]} \\
\end{array}$ & $\begin{array}{c}137.47 \\
(0.000) \\
{[0.51]} \\
\end{array}$ & $\begin{array}{c}180.74 \\
(0.000) \\
{[0.47]}\end{array}$ & 2 \\
\hline
\end{tabular}

Test statistic has asymptotic $\chi^{2}$-distribution with $3 \mathrm{~m}$ degrees of freedom under the null hypothesis ( $\mathrm{m}=$ number of regressors). The table shows the values of the test statistic and $\mathrm{p}$-values in parentheses and $\bar{R}^{2}$ in brackets.

Lag length of the transition variable is chosen based on the lowest p-value and - if p-values are the same - based on the goodness of fit measure $\bar{R}^{2}$.

Comparably, we also approach the choice between an ESTR and an LSTR model (cf. Teräsvirta (1994), (1998)). Following the rejection of the first null hypothesis (i.e. the model is regarded as non-linear), we test another null hypothesis (ii) $H_{0}: \varphi_{4}=0$ against $H_{A}: \varphi_{4} \neq 0$. Under the alternative, equation (6) would consist of an uneven degree polynomial, such that a rejection of the null hypothesis is regarded as a rejection of the ESTR model. Not rejecting the next null hypothesis (iii) $H_{0}: \varphi_{3}=0 \mid \varphi_{4}=0$ against $H_{A}: \varphi_{3} \neq 0 \mid \varphi_{4}=0$ can be seen as evidence in favour of an LSTR model. In a final step, one can test the hypothesis (iv) $H_{0}: \varphi_{2}=0 \mid \varphi_{3}=\varphi_{4}=0$ against $H_{A}: \varphi_{2} \neq 0 \mid \varphi_{3}=\varphi_{4}=0$. Rejection again points to the LSTR model. Teräsvirta (1994) argues, however, that in particular in small samples if the true model is an ESTR model which behaves closely to an LSTR model, the test often erroneously chooses an LSTR model. He suggests to compare the relative strengths of the rejections instead, i.e. the p-values. Because the test does not give clear-cut results for the selection of the transition function, we also apply another procedure, proposed by Escribano and Jordá (1999). They argue that using equation (6) does not capture all important features and suggest a second-order Taylor approximation yielding a slightly different auxiliary regression:

$$
\Delta x_{t}=\varphi_{0}+\varphi_{1} W_{t}+\varphi_{2} W_{t} z_{t-j}+\varphi_{3} W_{t} z_{t-j}^{2}+\varphi_{4} W_{t} z_{t-j}{ }^{3}+\varphi_{5} W_{t} z_{t-j}{ }^{4}+\epsilon_{t}
$$

The null hypotheses tested here are $H_{0 \mathrm{E}}: \varphi_{3}=\varphi_{5}=0$ and $H_{0 L}: \varphi_{2}=\varphi_{4}=0$. Escribano and Jordá suggest to choose an LSTR model if the lowest $p$-value is obtained for $H_{0 L}$ and an ESTR model if the lowest $p$-value is obtained for $H_{0 E}$. Results for the two tests can be found in table 4 . 
Table 4: Test for the appropriate specification

\begin{tabular}{|c|c|c|c|c|c|c|c|c|}
\hline & & \multicolumn{4}{|c|}{ Teräsvirta test } & \multicolumn{3}{|c|}{ Escribano Jordá test } \\
\hline Country & lags & (ii) & (iii) & (iv) & $\begin{array}{c}\text { Proposed } \\
\text { specification }\end{array}$ & $H_{0 E}$ & $H_{0 L}$ & $\begin{array}{l}\text { Proposed } \\
\text { specification }\end{array}$ \\
\hline Spain & 4 & $\begin{array}{l}48.32 \\
(0.000) \\
\end{array}$ & $\begin{array}{l}47.97 \\
(0.000) \\
\end{array}$ & $\begin{array}{l}43.52 \\
(0.000) \\
\end{array}$ & ESTR/LSTR & $\begin{array}{l}37.06 \\
(0.000) \\
\end{array}$ & $\begin{array}{l}46.80 \\
(0.000) \\
\end{array}$ & ESTR/LSTR \\
\hline Portugal & 6 & $\begin{array}{l}47.66 \\
(0.000)\end{array}$ & $\begin{array}{c}5.89 \\
(0.435)\end{array}$ & $\begin{array}{l}18.02 \\
(0.006)\end{array}$ & LSTR & $\begin{array}{c}6.56 \\
(0.584) \\
\end{array}$ & $\begin{array}{c}3.57 \\
(0.827) \\
\end{array}$ & ESTR \\
\hline Italy & 6 & $\begin{array}{l}47.11 \\
(0.000)\end{array}$ & $\begin{array}{l}28.36 \\
(0.001)\end{array}$ & $\begin{array}{c}8.29 \\
(0.405)\end{array}$ & ESTR/LSTR & $\begin{array}{l}32.05 \\
(0.000)\end{array}$ & $\begin{array}{l}19.80 \\
(0.031)\end{array}$ & ESTR \\
\hline France & 1 & $\begin{array}{l}12.20 \\
(0.032) \\
\end{array}$ & $\begin{array}{l}11.76 \\
(0.038) \\
\end{array}$ & $\begin{array}{c}5.53 \\
(0.355) \\
\end{array}$ & LSTR & $\begin{array}{l}14.68 \\
(0.066) \\
\end{array}$ & $\begin{array}{l}15.21 \\
(0.033) \\
\end{array}$ & LSTR \\
\hline Ireland & 4 & $\begin{array}{l}50.42 \\
(0.000) \\
\end{array}$ & $\begin{array}{l}16.70 \\
(0.054) \\
\end{array}$ & $\begin{array}{l}32.79 \\
(0.000) \\
\end{array}$ & LSTR & $\begin{array}{c}113.20 \\
(0.000) \\
\end{array}$ & $\begin{array}{l}96.53 \\
(0.000) \\
\end{array}$ & ESTR/LSTR \\
\hline Greece & 2 & $\begin{array}{l}72.42 \\
(0.000)\end{array}$ & $\begin{array}{l}54.98 \\
(0.000)\end{array}$ & $\begin{array}{l}70.47 \\
(0.000)\end{array}$ & ESTR/LSTR & $\begin{array}{c}158.03 \\
(0.000)\end{array}$ & $\begin{array}{l}15.50 \\
(0.050)\end{array}$ & ESTR \\
\hline
\end{tabular}

For the Teräsvirta test, $\chi^{2}$ test statistic realizations are displayed with $p$-values in parentheses. For the Escribano Jordá test, LM test statistics with asymptotic $\chi^{2}$ distribution are given with $p$-values in parentheses; degrees of freedom: $4(p+1)$.

Teräsvirta (1998) suggests estimating different models and choosing between the different specifications and different lag lengths only during evaluation of the estimation results. LSTR and ESTR models generally form very close substitutes. Tests as the ones above should thus be seen as a starting point for estimation instead of providing clear-cut outcomes. Some of the following results do therefore not match the originally proposed specifications; this could for instance be due to the outcomes of misspecifications tests or because the non-linear models did not converge.

\section{Estimation}

To evaluate our parameters, we estimate equation (2) with non-linear least squares (NLS). Our main coefficient of interest $\beta$ depends on the transition function $\mathrm{F}\left(\mathrm{z}_{\mathrm{t}-\mathrm{j}}, \gamma, \mathrm{c}\right)$ as depicted in either equation (4) or (5). To choose the final specifications, we examine our estimation results by simple judgment regarding the plausibility of the parameter values and the regimes which the models imply, the models' convergence properties, goodness of fit measures and a test of no residual autocorrelation. For this misspecification test we apply a variant of the Breusch-Godfrey Lagrange Multiplier (BG) test suitable for non-linear estimation as suggested in Teräsvirta (1998). The test's null hypothesis is that there is no $p^{\text {th }}$ order serial correlation in our residuals $u_{t}$. The test regresses $\widetilde{u}_{t}$ (the estimated residuals) on $\widetilde{u}_{t-1}, \ldots, \widetilde{u}_{t-p}$ and the partial derivatives of the regression function with respect to $\gamma$.

Estimation results are found in table 5 for countries with an ESTR specification and in table 6 for countries with an LSTR specification. ${ }^{12}$ Our theoretical priors suggest a negative coefficient for $\beta$, i.e. a substitution effect from domestic demand to exports during times of low or high capacity utilisation. When estimating the ESTR model, coefficient $\beta_{1 i}$ for $\mathrm{F}\left(\mathrm{z}_{\mathrm{t}-\mathrm{j}}, \gamma, \mathrm{c}\right)=0$ (i.e. the linear model) shows us results for capacity

${ }^{12}$ Complete estimation results are shown in table $A 3$ along with $R^{2}$ values and $p$-values for the test of no autocorrelation. 
utilisation levels around the threshold level. The joint coefficient $\beta_{1 i}+\beta_{2 i}$ for the case when $\mathrm{F}\left(\mathrm{z}_{\mathrm{t}-\mathrm{j}}, \gamma, \mathrm{c}\right)=1$ yields the results for positive and negative deviations from our threshold. In the LSTR case, $\beta_{1 i}$ represents low levels of capacity utilisation and $\beta_{1 i}+\beta_{2 i}$ high values of capacity utilisation. Figures 1 to 6 depict how $\beta$ evolves over the business cycle between the two respective extremes; $\beta$ is shown in combination with the transition variable $\mathrm{z}_{\mathrm{t}-\mathrm{j}}$ and defined as $\beta_{i}=\beta_{1 i}+\beta_{2 i} \cdot \mathrm{F}\left(\mathrm{z}_{\mathrm{t}-\mathrm{j}}, \gamma, \mathrm{c}\right)$.

Figure 1: Estimation Results for Spain $(c=0.780)$

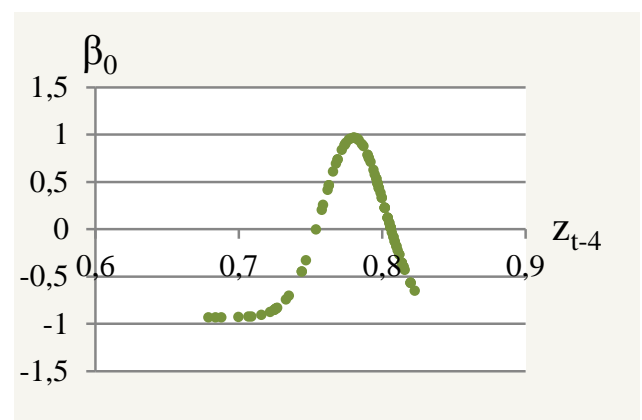

\section{Estimation Results}

Let us first turn to the countries for which the econometric specification warrants an ESTR model. As evident from figure 1, which is based on an ESTR model for Spain, $\beta_{0}$ displays negative values for low and to a certain degree also for high levels of past capacity utilisation. This suggests a substitutive relationship between domestic and foreign sales when the economy is close to peak or trough. When capacity utilisation is very low, firms react to a fall in domestic demand by increasing their efforts to export. Conversely, if the economy operates at high capacity utilisation, capacity constraints imply that an increase in domestic demand triggers a reallocation of resources from external to domestic clients. The estimation for Spain yields statistically significant results and the economic significance is also meaningful. For very low capacity utilisation (coefficient $\beta_{10}+\beta_{20}$ in table 5), a one percentage point fall in domestic demand generates close to a one percentage point increase in exports. For peak times, this elasticity is slightly lower. By contrast, a positive link is identified between domestic demand and exports during normal economic conditions (coefficient $\beta_{10}$ ). It is likely that during this interval, the short-run liquidity channel dominates, whereby the cash flow generated by exports is used to finance domestic operations and the existence of increasing returns dominates the capacity constraints channel (Berman et al. (2011)). As argued above, this general pattern is in line with the prevalence of hysteresis and the band of inaction due to switching costs for suppliers between serving the domestic and foreign market. 

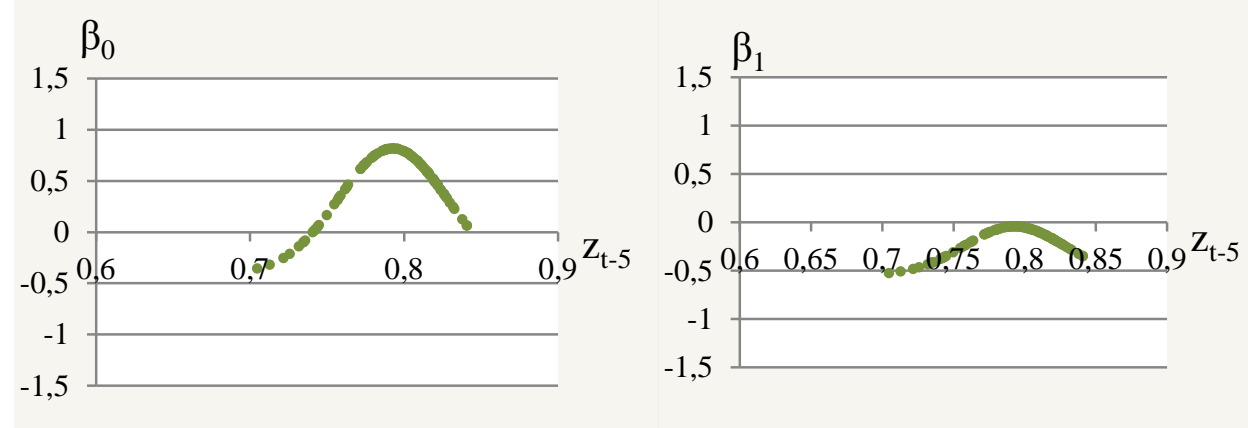

Figure 3: Estimation Results for Italy $(c=0.751)$
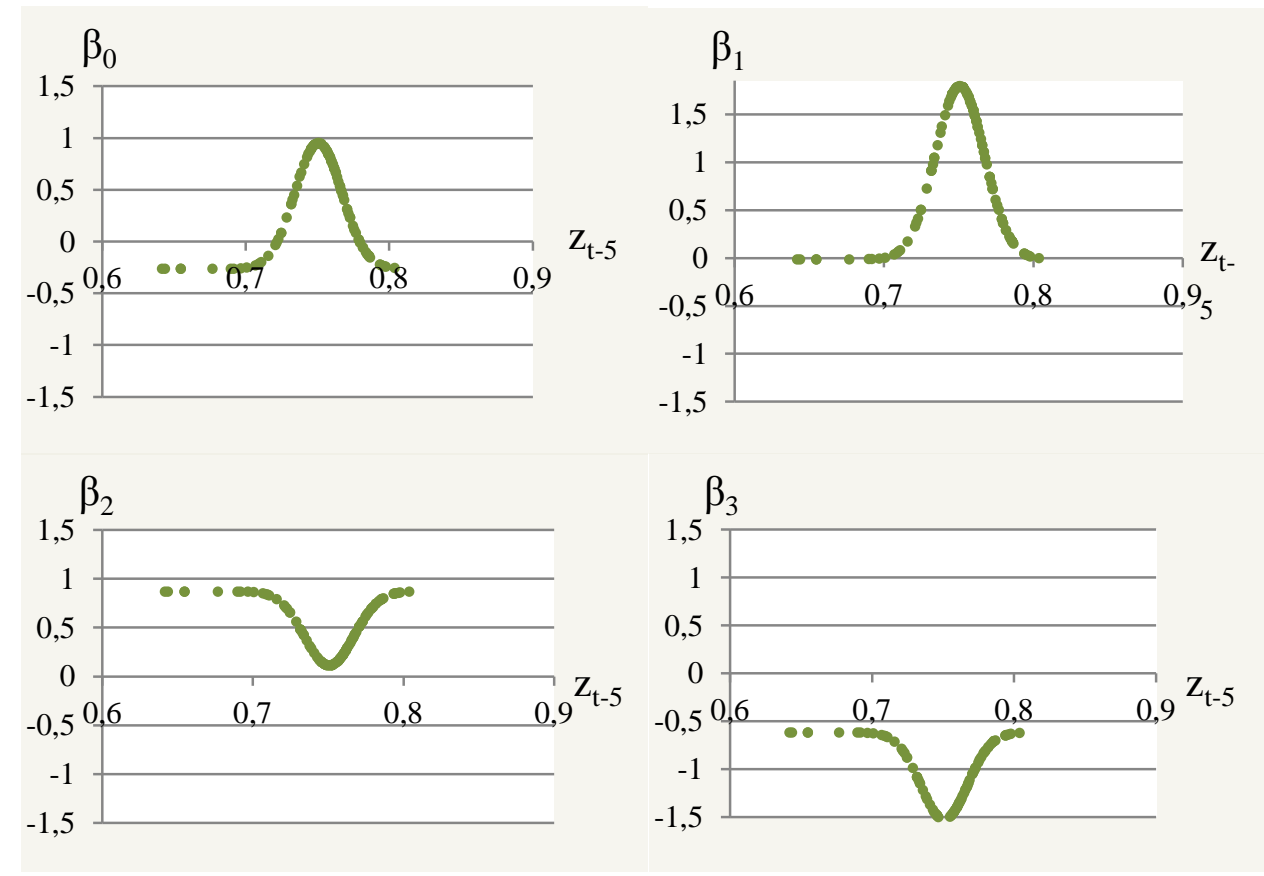

Similar results (though somewhat less strong in economic terms) are found for Portugal as evident in figure 2. Both the contemporaneous effect and the first lag yield a negative coefficient for the domestic demandexport relation during extreme capacity utilisation values $\left(\beta_{10}+\beta_{20}\right.$ and $\left.\beta_{11}+\beta_{21}\right)$. For Italy, shown in figure 3 , results are somewhat mixed. Here, the small contemporaneous substitution effect during trough and peak $\left(\beta_{10}+\beta_{20}\right)$ is found not to be different from zero contrary to the statistically significant positive coefficient for normal times; this also holds for the first lag of the coefficient on domestic demand. The third lag, on the other hand, yields relatively sizeable negative coefficients for all capacity utilisation values. Overall, the results suggest that there might be a net substitution effect. This indicates that, as a reaction to a negative domestic demand shock, firms which are already in the export market and have thus already incurred market entry costs tend to sell relatively less to the domestic market and just switch to foreign markets or new firms would enter the export market. During normal economic times, the relationship is 
more complementary for both Portugal and Italy. As former entry costs can be considered to be sunk, one could argue that in order to avoid exiting the markets and paying entry costs anew in the future (Belke and Goecke (2005)), firms try to serve both domestic and foreign markets.

The results for France (figure 4) do not correspond to our theoretical priors but with the results by Berman et al. (2011) who found that exports and domestic sales are not substitutive but complementary for a panel of French firms. Our results also show that this complementary relationship holds over the entire values of the transition variable and is not as strong as it is for other countries; we find an elasticity between 0.4 and 0.5. In addition, for France, the test on non-linearity did not reject linearity as strongly as it did for the other countries. Rather, linearity was only rejected for low lag lengths of the transition variable. The estimation results for France pointed to an ESTR specification while the specification tests suggested an LSTR model; this could also be due to the fact that non-linearity is not as strong as it is for other countries. Figure 4 confirms the notion that non-linearity might not play an important role for the French data. One possible explanation could be that the French business cycle in the years under consideration did not vary as much as that of the other countries. The overall finding of no substitutive relationship may also be related to the lower openness of the French economy and potentially the lower foreign demand elasticity of French exports. Generally, the effect of increases in marginal costs gains importance with foreign demand elasticity, which makes a substitutive relationship between domestic demand and exports more likely in small open economies characterized by highly elastic foreign demand.

\section{Figure 4: Estimation Results for France $(c=0.847)$}

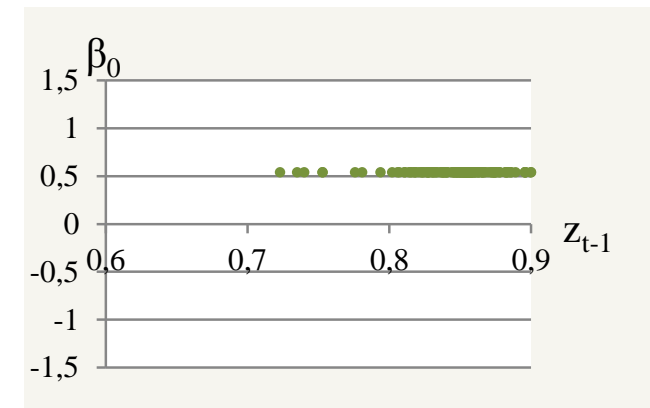

Looking at Ireland and Greece, the two countries for which we estimate an LSTR model, we equally find at least weak evidence for a negative link between domestic and foreign sales during periods of low capacity utilisation (figures 5 and 6 ; coefficients $\beta_{1 i}$ in table 6). This effect, however, is statistically insignificant for both countries and economically only of very modest size. For Greece, the coefficient $\beta_{1 i}$ also shows different qualitative results for higher lag lengths. After passing a critical threshold, exports and domestic 
Table 5: Estimation results for domestic demand - ESTR specification

\begin{tabular}{|c|c|c|c|c|c|}
\hline & & Spain & Portugal & Italy & France \\
\hline Contempora & $\begin{array}{l}\text { lag length of } \\
\text { transition variable } \\
\text { us coefficients }\end{array}$ & 4 & 5 & 5 & 1 \\
\hline \multirow[t]{2}{*}{$Z \rightarrow C$} & $\beta_{10}$ & $\begin{array}{c}0.964 * * * \\
(0.22)\end{array}$ & $\begin{array}{c}0.812 * * * \\
(0.25)\end{array}$ & $\begin{array}{c}0.950 * * \\
(0.46)\end{array}$ & $\begin{array}{c}0.535^{* *} \\
(0.23)\end{array}$ \\
\hline & $\beta_{20}$ & $\begin{array}{c}-1.897 * * * \\
(0.22)\end{array}$ & $\begin{array}{c}-1.224^{* * *} \\
(0.27)\end{array}$ & $\begin{array}{c}-1.214^{* * * *} \\
(0.38)\end{array}$ & $\begin{array}{r}-0.135 \\
(0.356)\end{array}$ \\
\hline$z \rightarrow \pm \infty$ & $\beta_{10}+\beta_{20}$ & $\begin{array}{c}-0.933^{* * *} \\
{[0.00]}\end{array}$ & $\begin{array}{c}-0.410 \\
{[0.32]}\end{array}$ & $\begin{array}{c}-0.264 \\
{[0.54]}\end{array}$ & $\begin{array}{c}0.399 * * \\
{[0.02]}\end{array}$ \\
\hline \multicolumn{6}{|c|}{ Lagged coefficients with 1 lag } \\
\hline \multirow[t]{2}{*}{$z \rightarrow c$} & $\beta_{11}$ & - & $\begin{array}{c}-0.046 \\
(0.13)\end{array}$ & $\begin{array}{c}1.791^{* * *} \\
(0.61)\end{array}$ & - \\
\hline & $\beta_{21}$ & - & $\begin{array}{c}-0.501 \\
(0.42)\end{array}$ & $\begin{array}{c}-1.806^{*} \\
(1.00)\end{array}$ & - \\
\hline$z \rightarrow \pm \infty$ & $\beta_{11}+\beta_{21}$ & - & $\begin{array}{c}-0.547^{*} \\
{[0.08]}\end{array}$ & $\begin{array}{c}-0.015 \\
{[0.97]}\end{array}$ & - \\
\hline \multicolumn{6}{|c|}{ Lagged coefficients with 2 lags } \\
\hline \multirow[t]{2}{*}{$z \rightarrow c$} & $\beta_{12}$ & - & - & $\begin{array}{l}0.110 \\
(0.49)\end{array}$ & - \\
\hline & $\beta_{22}$ & - & - & $\begin{array}{c}0.758^{* *} \\
(0.33)\end{array}$ & - \\
\hline$z \rightarrow \pm \infty$ & $\beta_{12}+\beta_{22}$ & - & - & $\begin{array}{c}0.868 \\
{[0.12]}\end{array}$ & - \\
\hline \multicolumn{6}{|c|}{ Lagged coefficients with 3 lags } \\
\hline \multirow[t]{2}{*}{$z \rightarrow c$} & $\beta_{13}$ & - & - & $\begin{array}{c}-1.526^{* * *} \\
(0.56)\end{array}$ & - \\
\hline & $\beta_{23}$ & - & - & $\begin{array}{c}0.907 \\
(0.64)\end{array}$ & - \\
\hline \multirow[t]{4}{*}{$z \rightarrow \pm \infty$} & $\beta_{13}+\beta_{23}$ & - & - & $\begin{array}{c}-0.619 * * * \\
{[0.00]}\end{array}$ & - \\
\hline & $\gamma$ & $\begin{array}{c}35.566 * \\
(18.61)\end{array}$ & $\begin{array}{c}12.907 \\
(13.46)\end{array}$ & $\begin{array}{c}59.061 * * * \\
(20.89)\end{array}$ & $\begin{array}{c}1.6381^{* *} \\
(0.684)\end{array}$ \\
\hline & $\mathrm{R}^{2}$ & 0.773 & 0.487 & 0.603 & 0.568 \\
\hline & $\begin{array}{l}\mathrm{p} \text {-value } \\
\text { BG test }\end{array}$ & 0.506 & 0.592 & 0.741 & 0.110 \\
\hline
\end{tabular}

Coefficients estimated by NLS; Newey-West standard errors in parentheses. * $/ * * / * * *$ statistical significance at the $10 \% / 5 \% / 1 \%$ level. For the joint significance of $\beta_{1 i}$ and $\beta_{2 i}$, the linear restriction $\beta_{1 i}+\beta_{2 i}=0$ has been tested with Chi-squared test statistics; $p$-value in brackets. The BreuschGodfrey Lagrange Multiplier (BG) test is based on the null hypothesis of no serial correlation of the residuals of order $p=4$.

$\beta_{j i}(j=1,2)$ is the coefficient for domestic demand in the non-linear error correction model. The two extreme regimes are

$\mathrm{F}\left(\mathrm{z}_{\mathrm{t}-\mathrm{j}}, \gamma, \mathrm{c}\right)=0$ given by $\beta_{1 i}$ (i.e. for the ESTR model around the threshold value) and $\mathrm{F}\left(\mathrm{z}_{\mathrm{t}-\mathrm{j}}, \gamma, \mathrm{c}\right)=1$ given by $\beta_{1 i}+\beta_{2 i}$ (i.e. for the ESTR model for large deviations from threshold).

demand become complements with an increasing degree of capacity utilisation (coefficient $\beta_{10}+\beta_{20}$; again, for Greece the higher lag lengths for coefficients $\beta_{1 i}+\beta_{2 i}$ yield different outcomes). A further threshold, for positive domestic demand shocks and high capacity utilisation is not reached. For both countries, therefore, the band of inaction is only restricted to one side. In the case of Ireland, the finding that only economic recessions but not periods of booms might lead to a substitutive relationship between domestic and export sales may be explained by the higher flexibility of the Irish economy compared to its Southern European counterparts. Flexible prices and immigration may have made capacity constraints less binding. At the same time, the overall small coefficients around zero (both positive and negative) might be due to the large 
number of multinational corporations in Ireland, which are presumably less tied to the domestic situation and should therefore react less to domestic demand shocks than firms with a strong domestic focus.

Figure 5: Estimation Results for Ireland $(c=-0.330)$
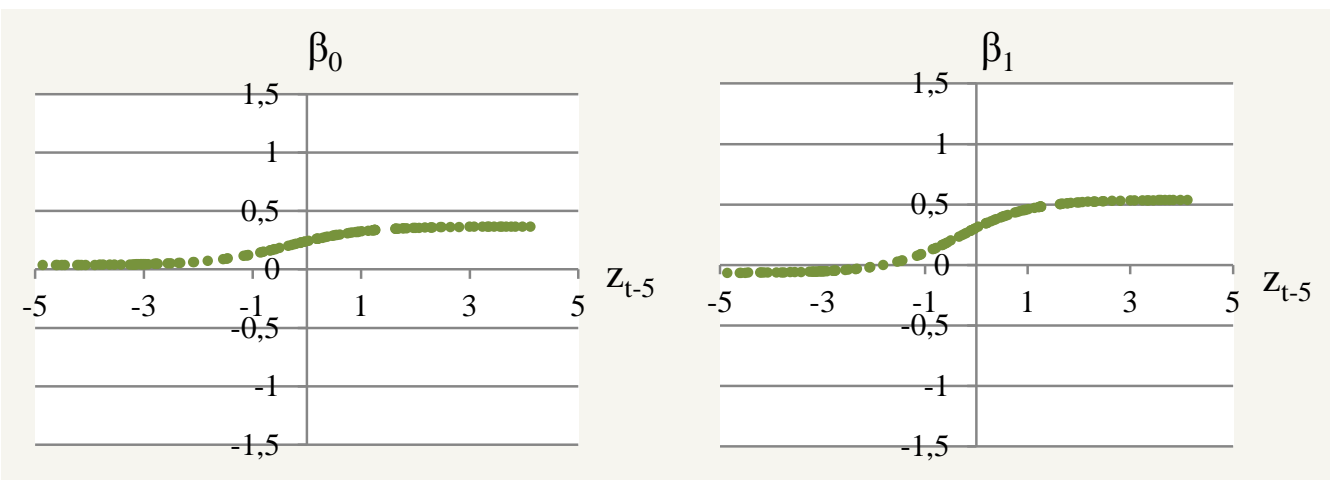

For Greece, the estimated model somewhat resembles a simple two-regime threshold model where marginal changes of capacity utilisation around its average have strong effects on the relation between domestic demand and exports. Further strong changes, however, do not have any additional effects. Also, at least during the time period under consideration, Greece has never displayed a capacity utilisation rate of more than 80 percent and its average degree of utilisation is much lower than that of the other countries. This could explain why the band of inaction for Greece seems to be restricted only to the side of low capacity utilisation. The interlinkages between exports and domestic demand changes under high capacity utilisation rates remain unknown. Results seem to be less robust during longer lag lengths. Finally, it needs to be noted that the weak substitutive relation could be due to the fact that there is no strong tradable sector in Greece.

Figure 6: Estimation Results for Greece $(c=0.748)$
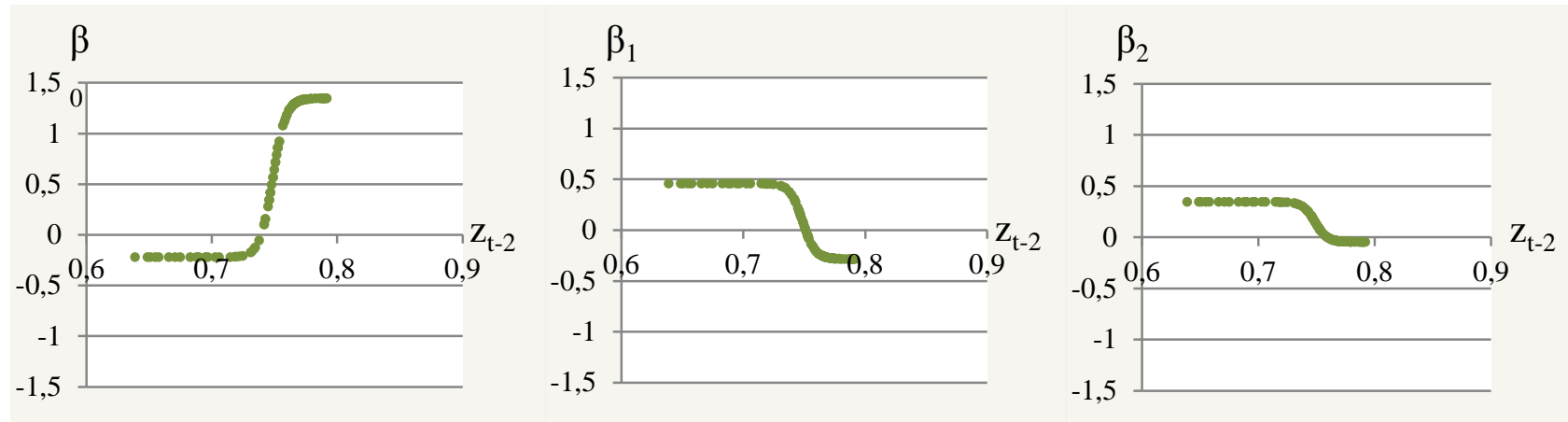

Overall, our empirical results suggest that the relationship between domestic sales and exports depends on capacity utilisation and the business cycle. A substitutive relationship between domestic and foreign sales is evident during economic downturns when capacities are only weakly utilised; we obtain a negative coefficient in most countries, though these do not always turn out statistically significant and vary with 
different lag lengths. ${ }^{13}$ The finding is, however, broadly in line with the gain in export market shares in several euro area crisis countries during the current recession. There is more diversity across countries during other stages of the business cycle suggesting that capacity constraints and the liquidity channel play a different role across countries and/or partly cancel each other out.

Table 6: Estimation results for domestic demand - LSTR specification

\begin{tabular}{|c|c|c|c|}
\hline & & Ireland & Greece \\
\hline & $\begin{array}{c}\text { lag length of transition } \\
\text { variable }\end{array}$ & 5 & 2 \\
\hline \multicolumn{4}{|c|}{ Contemporaneous coefficients } \\
\hline \multirow[t]{2}{*}{$z \rightarrow-\infty$} & $\beta_{10}$ & $\begin{array}{c}0.035 \\
(0.12)\end{array}$ & $\begin{array}{c}-0.226 \\
(0.20)\end{array}$ \\
\hline & $\beta_{20}$ & $\begin{array}{c}0.330 * * \\
(0.13)\end{array}$ & $\begin{array}{c}1.569 * * * \\
(0.31)\end{array}$ \\
\hline$z \rightarrow+\infty$ & $\beta_{10}+\beta_{20}$ & $\begin{array}{l}0.364^{* * * *} \\
{[0.00]}\end{array}$ & $\begin{array}{c}1.343^{* * *} \\
{[0.00]}\end{array}$ \\
\hline \multicolumn{4}{|c|}{ Lagged coefficients with 1 lag } \\
\hline \multirow[t]{2}{*}{$z \rightarrow-\infty$} & $\beta_{11}$ & $\begin{array}{c}-0.068 \\
(0.16)\end{array}$ & $\begin{array}{c}0.454^{* * *} \\
(0.17)\end{array}$ \\
\hline & $\beta_{21}$ & $\begin{array}{c}0.604^{* *} \\
(0.28)\end{array}$ & $\begin{array}{c}-0.743 * * * \\
(0.27)\end{array}$ \\
\hline$z \rightarrow+\infty$ & $\beta_{11}+\beta_{21}$ & $\begin{array}{c}0.659 * * * \\
{[0.00]}\end{array}$ & $\begin{array}{c}-0.289 * * \\
{[0.04]}\end{array}$ \\
\hline \multicolumn{4}{|c|}{ Lagged coefficients with 2 lags } \\
\hline \multirow[t]{2}{*}{$z \rightarrow-\infty$} & $\beta_{12}$ & - & $\begin{array}{l}0.341 \\
(0.22)\end{array}$ \\
\hline & $\beta_{22}$ & - & $\begin{array}{c}-0.390 * \\
(0.23)\end{array}$ \\
\hline \multirow[t]{4}{*}{$z \rightarrow+\infty$} & $\beta_{12}+\beta_{22}$ & - & $\begin{array}{c}-0.049 \\
{[0.86]}\end{array}$ \\
\hline & $\gamma$ & $\begin{array}{c}3.842^{*} \\
(2.20)\end{array}$ & $\begin{array}{c}6.662 * * * \\
(2.29)\end{array}$ \\
\hline & $\mathrm{R}^{2}$ & 0.688 & 0.686 \\
\hline & $\begin{array}{l}\mathrm{p} \text {-value } \\
\text { BG test }\end{array}$ & 0.104 & 0.714 \\
\hline
\end{tabular}

Coefficients estimated by NLS; Newey-West standard errors in parentheses. ***/*** statistical significance at the $10 \% / 5 \% / 1 \%$ level. For the joint significance of $\beta_{1 i}$ and $\beta_{2 i}$, the linear restriction $\beta_{1 i}+\beta_{2 i}=0$ has been tested with Chi-squared test statistics; $p$-value in brackets. The BreuschGodfrey Lagrange Multiplier (BG) test is based on the null hypothesis of no serial correlation of the residuals of order $p=4 . \beta_{j i}(j=1,2)$ is the coefficient for domestic demand in the non-linear error correction model. The two extreme regimes are $\mathrm{F}\left(\mathrm{z}_{\mathrm{t}-\mathrm{j}}, \gamma, \mathrm{c}\right)=0$ given by $\beta_{1 i}$ (i.e. for the LSTR model for large negative deviations from the threshold) and $\mathrm{F}\left(\mathrm{z}_{\mathrm{t}-\mathrm{j}}, \gamma, \mathrm{c}\right)=1$ given by $\beta_{1 i}+\beta_{2 i}$ (i.e. for LSTR for large positive deviations from threshold).

Besides the effect of domestic demand on exports, we are also interested in the adjustment coefficient $\delta$. This adjustment effect shows how much of long-run disequilibrium is being corrected in each period. In particular, the coefficient tells us the extent to which disequilibrium in the previous period has an impact on export adjustments. If there was a negative shock and exports in the previous period $\left(x_{t-1}\right)$ were below its long-run equilibrium path, the value of $\hat{\varepsilon}_{t-1}$ from equation (3) would turn negative. Because we add $\delta$ with a positive sign in the error-correction model of equation (2), we expect a negative adjustment coefficient in order for $\Delta x_{t}$ to return to the long-run equilibrium. The opposite holds for a positive shock to exports. The

${ }^{13}$ In case of the ESTR model (for Spain, Portugal, Italy and France) the coefficient of interest for strong economic downturns is $\beta_{1 i}+\beta_{2 i}$, for the LSTR model (Ireland and Greece) it is $\beta_{1 i}$. 
speed with which exports return to equilibrium depends on the size of $\delta$. In our specification, this adjustment coefficient depends on the transition function (and therefore the transition variable). To show the adjustment effect for the respective countries over the business cycle (i.e. as the transition variable changes), coefficient $\delta=\delta_{1}+\delta_{2} \cdot \mathrm{F}\left(\mathrm{z}_{\mathrm{t}-\mathrm{j}}, \gamma, \mathrm{c}\right)$ is displayed in figure 7 for the different countries.

\section{Figure 7: Adjustment coefficients}

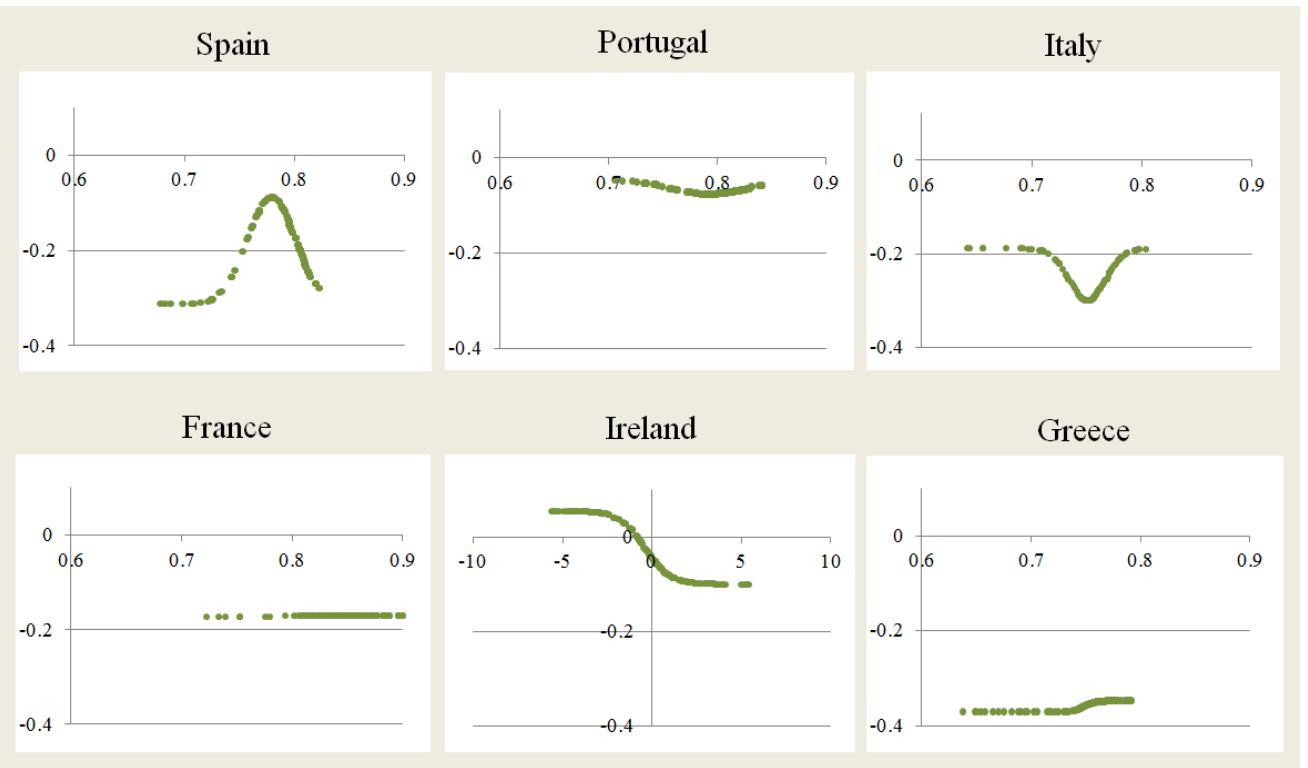

The figures refer to coefficient $\delta$ which is depicted on the vertical axis; $\delta$ is defined as $\delta=\delta_{1}+\delta_{2} \cdot \mathrm{F}\left(\mathrm{z}_{\mathrm{t}-\mathrm{j}}, \gamma, \mathrm{c}\right)$. The transition variable $z_{t-j}$ is displayed on the horizontal axis.

For Spain and Italy, the adjustment coefficient turns out to be somewhere between -0.1 and -0.3 depending on the state of the economy, i.e. 10 to 30 per cent of the adjustment from disequilibrium takes place in one quarter. The adjustment for France and Greece does not vary this much over the business cycle and ranges from 30 to about $37 \%$. For Portugal and Ireland, the case is different: the adjustment ranges from $20 \%$ or $11 \%$ respectively to an adjustment coefficient around zero (and even slightly positive) during strong economic downturns. This implies that during bad economic times, there is no adjustment at all.

\section{Robustness Tests}

In the following, we are performing some robustness for our estimations. We begin with considering value added exports rather than gross exports. ${ }^{14}$ By disregarding imported intermediate goods, we obtain a measure which is more closely related to capacity constraints. Due to data availability reasons, the sample had to be restricted to the period until 2011. Moreover, as the long-run relation can be sensitive to further

\footnotetext{
${ }^{14}$ Belke et al. (2014) present results for using export goods only and yield similar results.
} 
structural breaks or omitted variables, in a further test we drop the long-run coefficient altogether. ${ }^{15}$ The results of our robustness tests can be found in figures 8 and 9 and tables A4-A5.

Figure 8: Estimation with value added exports

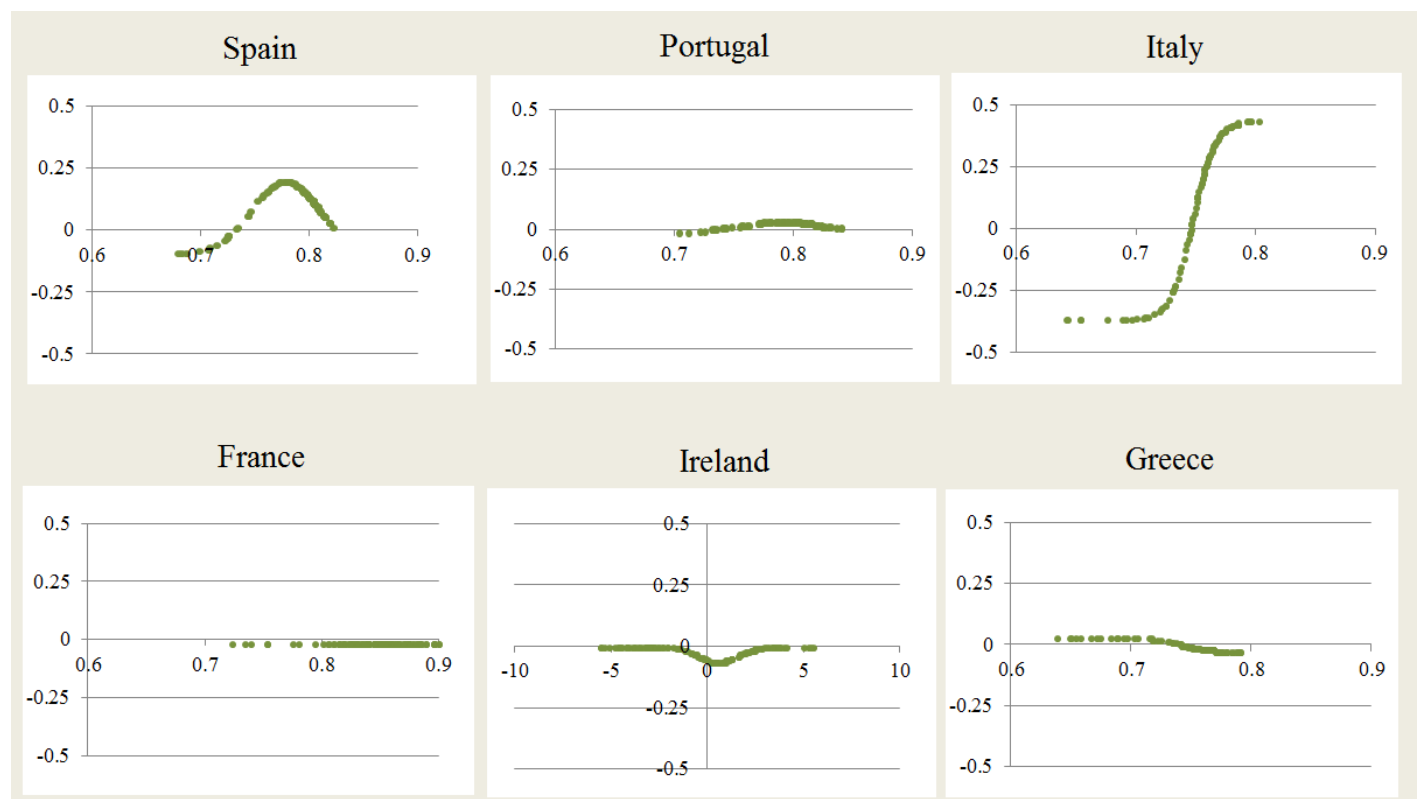

The figures refer to coefficient $\beta_{0}$ which is depicted on the vertical axis; $\beta_{0}$ is defined as $\beta_{0}=\beta_{10}+\beta_{20} \cdot \mathrm{F}\left(\mathrm{z}_{\mathrm{t}-\mathrm{j}}, \gamma, \mathrm{c}\right)$. The transition variable $z_{t-j}$ is displayed on the horizontal axis.

Overall, the findings confirm the results we presented above with slight refinements. For Spain and Portugal, the results for the different estimations strongly resemble the original estimations, even though the size of the coefficients decreases considerably when employing value added exports (the same holds for the other countries' results). For Italy, the main finding - namely a substitutive relation between domestic demand and exports during low capacity utilisation - is confirmed in all of the robustness estimations, even though the specification changed from an ESTR to an LSTR model in some cases. The upper threshold for the band of inaction thus seems to be less robust. The original estimation for France showed that non-linearity was less important; it also found a slightly positive relation between domestic demand and exports throughout different values of capacity utilisation. This result is confirmed by most of the robustness estimations, with even smaller coefficients around zero. For Ireland, we also find only weak non-linearities and coefficients around zero in all of our robustness estimations. This again strongly resembles our original findings, reflecting the high flexibility of the Irish economy. Lastly, for Greece we confirm the finding of a coefficient around zero for low capacity utilisation levels.

\footnotetext{
${ }^{15}$ We also perform additional robustness tests by using different types of real effective exchange rates (deflated by unit labor costs and deflated by consumer price indices) and using the median instead of the mean value as threshold. Results are available upon request.
} 


\section{Figure 9: Estimation without long-run adjustment coefficient}
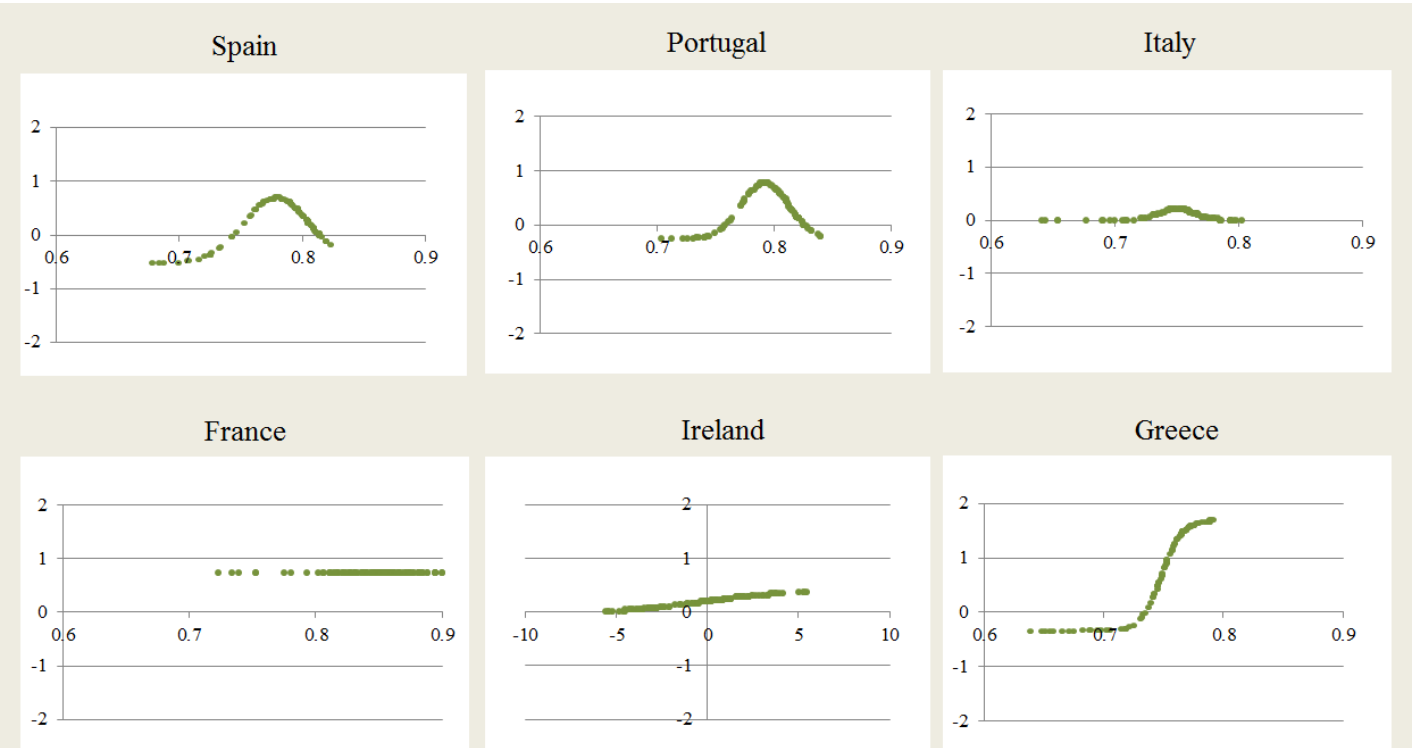

The

refer to coefficient $\beta_{0}$ which is depicted on the vertical axis; $\beta_{0}$ is defined as $\beta_{0}=\beta_{10}+\beta_{20} \cdot \mathrm{F}\left(\mathrm{z}_{\mathrm{t}-\mathrm{j}}, \gamma, \mathrm{c}\right)$. The transition variable $z_{t-j}$ is displayed on the horizontal axis.

\section{Conclusions}

In this paper, we have analysed the relation between domestic demand and exports for six euro area countries using non-linear smooth transition estimations. The results indicate that domestic demand behaviour is relevant for the short-run dynamics of several euro area member countries' exports. The estimation results suggest that on an aggregated level, contemporary and lagged domestic demand developments can affect a country's export performance significantly. In the cases of Spain, Portugal and Italy, the symmetric non-linearity of the relation expresses itself in a contemporary substitutive relationship between domestic demand and export activity if deviations from average capacity utilisation are large; this is somewhat independent of their sign, but we find stronger evidence for notably low levels of capacity utilisation. In other words, the substitution effect from domestic demand to exports turns out to be stronger and more significant during more extreme stages of the business cycle. During periods of more average levels of capacity utilisation, our empirical evidence points to a band of inaction in which the relation between domestic and foreign sales is complementary. On a micro level, theoretical reasons for these findings can be found in the sunk costs hysteresis approach. For France, the evidence for non-linearity is weaker. We find evidence for mostly complementary relationships. In the cases of Ireland and Greece, we find an asymmetric non-linear relationship between domestic demand and exports. Domestic demand and exports are slightly substitutive during a business cycle trough and complements during normal times and in a boom.

Overall, our results mostly confirm the short-run non-linear relationship between domestic and foreign sales depending on capacity constraints. A substitutive relationship with low capacity utilisation shows up most 
clearly for Spain, Portugal and Italy. We provide first ideas for why we believe there are valid reasons for the different findings in the other countries (such as the high number of multinational corporations in Ireland, the lower openness of the French economy or the small Greek tradable sector). However, more detailed explanations for these heterogeneous results for some countries in our sample provide an interesting area for future research. A further interesting avenue could lead to a more disaggregated, sectoral analysis to understand the underlying firm behaviour in more detail. For our purpose, however, the macroeconomic perspective is able to offer insights on overall adjustment effects for euro area countries with previous imbalances.

In recent years, the six countries under consideration which recorded large current account deficits before the crisis have seen a significant correction of their external imbalances. This holds in particular for their trade balances, and exports have been a key adjustment factor. Our results provide one explanation for the rising exports besides standard competitiveness arguments; the observed increase in export market shares accompanying the reduction of the current account deficits could be due to non-price related factors, such a low domestic demand leading to survival-driven exports, instead of an increase in price competitiveness as expected by sustainable structural reforms. This argument appears to be especially relevant in the current period for the countries under consideration in which their capacities have been utilised only to a low degree and domestic demand has fallen strongly. Low domestic demand then did not only affect imports, but at the same time exports and has thus strongly contributed to the external adjustment.

Regarding policy implications, our findings provide important insights for the discussion of macroeconomic adjustment and the reduction of imbalances in the euro area. Prima facie, our results could suggest that domestic demand and exports are negatively related only in the short-run, triggered by current economic conditions. To the extent that the closure of the output gap is driven by a pick-up in domestic demand, a lot of the gains in export market shares of vulnerable euro area countries could be lost in the long-run. In such a scenario, analyses of cyclically adjusted current account balances could possibly overestimate the structural adjustment to the degree that weak domestic economic conditions impact not only the import side of the net trade equation, but also the export side.

On the other hand, at least three factors give rise to the hope that the gains in export market performance may be of a more long-run nature. First, domestic demand conditions in peripheral economies are likely to remain depressed as long as the debt burden of both private and public sector remains high. An extended period of deleveraging pressure increases the chances that the reallocation of resources to the export sector will also be more permanent, possibly also fostering increased export-oriented foreign direct investment into distribution networks and other hedging activities (Belke et al. 2013). This would make the hypothesized substitutive relationship between domestic demand and exports more long-run. Second, our sunk-cost hysteresis model suggests that once domestic producers have paid sunk costs for shifting production to exports, they remain in a band of inaction even as the business cycle improves. Reversing export market 
participation should not be expected as long as there are capacities for serving both domestic and foreign market. Third, with increasing exports today and a pick-up in domestic demand in the future, a complementary relation between domestic sales and exports might develop in the long-run due to improvements in efficiency encouraged by learning-by-doing effects. In conclusion, the export increase could therefore be lasting and a substantial part of the gains in export market shares may not only a cyclical phenomenon, but indeed be of a more structural nature. 


\section{Appendix}

Table A1: Data Sources

\begin{tabular}{|c|c|c|c|}
\hline Series & Source & Definition & time periods available \\
\hline Exports & $\begin{array}{l}\text { National Statistical } \\
\text { Offices }\end{array}$ & $\begin{array}{c}\text { real exports of goods and services (in prices } \\
\text { of reference year) }\end{array}$ & $\begin{array}{l}\text { 1980Q1 - 2012Q4; } \\
\text { IT: 1981Q1 - 2012Q4 }\end{array}$ \\
\hline $\begin{array}{l}\text { Exports } \\
\text { (Value Added) }\end{array}$ & $\begin{array}{l}\text { World Input- } \\
\text { Output Database } \\
\text { (interpolated) }\end{array}$ & $\begin{array}{l}\text { value added exports (converted to prices of } \\
\text { reference year) }\end{array}$ & 1995Q1 - 2011Q1 \\
\hline $\begin{array}{l}\text { Domestic } \\
\text { Demand }\end{array}$ & $\begin{array}{l}\text { National Statistical } \\
\text { Offices }\end{array}$ & $\begin{array}{c}\text { real domestic demand (in prices of reference } \\
\text { year) }\end{array}$ & $\begin{array}{l}\text { 1980Q1 - 2012Q4; } \\
\text { IT: 1981Q1 - 2012Q4 }\end{array}$ \\
\hline $\begin{array}{l}\text { Real Effective } \\
\text { Exchange Rate } \\
\text { (CPI) }\end{array}$ & Eurostat & $\begin{array}{l}\text { index deflated by consumer price indices } \\
\text { with a country's } 15 \text { main trading partners }\end{array}$ & 1980Q1 - 2012Q4 \\
\hline $\begin{array}{l}\text { Real Effective } \\
\text { Exchange Rate } \\
\text { (ULC) }\end{array}$ & Eurostat & $\begin{array}{l}\text { index deflated by unit labour costs with a } \\
\text { country's } 24 \text { main trading partners }\end{array}$ & 1980Q1 - 2012Q4 \\
\hline Foreign Demand & $\mathrm{ECB}$ & $\begin{array}{l}\text { trade-weighted imports for } 15 \text { main trading } \\
\text { partners }\end{array}$ & $1980 Q 1-2012 Q 4$ \\
\hline $\begin{array}{l}\text { Capacity } \\
\text { Utilisation }\end{array}$ & Eurostat & $\begin{array}{c}\text { current level of capacity utilisation in } \\
\text { manufacturing industry based on business } \\
\text { surveys }\end{array}$ & $\begin{array}{l}\text { PT: 1987Q1 - 2012Q4; } \\
\text { IT, GR: 1985Q1 - 2012Q4; } \\
\text { ES: 1987Q2 - 2012Q4 }\end{array}$ \\
\hline $\begin{array}{l}\text { Capacity } \\
\text { Utilisation }\end{array}$ & Insee & $\begin{array}{l}\text { capacity utilisation rate based on quarterly } \\
\text { business survey }\end{array}$ & FR: 1980Q1 - 2012Q4 \\
\hline Output Gap & $\begin{array}{c}\text { AMECO } \\
\text { (interpolated) }\end{array}$ & $\begin{array}{c}\text { gap between actual GDP and potential GDP } \\
\text { as percentage of potential GDP }\end{array}$ & IE: 1980Q1 - $2012 Q 4$ \\
\hline
\end{tabular}


Table A2: Unit Root Tests

\begin{tabular}{|c|c|c|c|c|c|}
\hline & & \multicolumn{2}{|c|}{ ADF test } & \multicolumn{2}{|c|}{ Lee-Strazicich test } \\
\hline & & Level & $1^{\text {st }}$ Diff. & 1 break & 2 breaks \\
\hline Country & Series & t-stat. [lags] & t-stat. [lags] & t-stat. & t-stat. \\
\hline \multirow{7}{*}{ Spain } & $d d_{t}$ & $-1.054[3]$ & $-2.111 * *[2]$ & -0.6281 & -0.6370 \\
\hline & $x_{t}$ & $-1.275[0]$ & $-10.565^{* * *}[0]$ & -1.7927 & -2.0560 \\
\hline & $x_{t}^{\text {goods }}$ & $-1.875[0]$ & $-12.457 * * *[0]$ & -2.4443 & -2.9754 \\
\hline & $x_{t}^{v a}$ & $-2.407[8]$ & $-2.093 * *[10]$ & -0.7349 & -0.7597 \\
\hline & $y_{t}^{*}$ & $-3.418 *[1]$ & $-4.569 * * *[0]$ & -1.9472 & -2.0878 \\
\hline & $r_{t}$ & $-1.250[1]$ & $-8.763^{* * *}[0]$ & -1.8106 & -1.9323 \\
\hline & $r_{t}^{U L C}$ & $-1.373[1]$ & $-7.905 * * *[0]$ & -1.0327 & -1.0664 \\
\hline \multirow{7}{*}{ Portugal } & $d d_{t}$ & $-0.199[3]$ & $-3.017 * * *[2]$ & -0.5972 & -0.6117 \\
\hline & $x_{t}$ & $-0.731[0]$ & $-7.321 * * *[0]$ & -1.4594 & -1.5466 \\
\hline & $x_{t}^{\text {goods }}$ & $-1.967[4]$ & $-3.257^{* * *}[3]$ & -2.6350 & -2.9542 \\
\hline & $x_{t}^{v a}$ & $-0.750[8]$ & $-1.843 *[3]$ & -1.1552 & -1.1895 \\
\hline & $y_{t}^{*}$ & $-2.742[1]$ & $-4.400 * * *[0]$ & -1.6444 & -1.7162 \\
\hline & $r_{t}$ & $-1.353[1]$ & $-8.784^{* * *}[0]$ & -2.4693 & -2.5850 \\
\hline & $r_{t}^{U L C}$ & $-0.917[1]$ & $-6.849 * * *[0]$ & -1.0068 & -1.0402 \\
\hline \multirow{7}{*}{ Italy } & $d d_{t}$ & $-0.153[2]$ & $-3.637 * * *[1]$ & -0.7875 & -0.8090 \\
\hline & $x_{t}$ & $-1.318[0]$ & $-5.907 * * *[1]$ & -2.0700 & -2.3491 \\
\hline & $x_{t}^{\text {goods }}$ & $-3.906^{* *}[2]$ & $-8.076 * * *[0]$ & -2.5597 & -2.9079 \\
\hline & $x_{t}^{v a}$ & $-3.251 *[7]$ & $-2.585^{* *}[7]$ & -1.4249 & -1.4481 \\
\hline & $y_{t}^{*}$ & $-2.944[2]$ & $-4.750 * * *[1]$ & -2.0089 & -2.1816 \\
\hline & $r_{t}$ & $-2.501[1]$ & $-8.336 * * *[0]$ & -1.8317 & -1.9321 \\
\hline & $r_{t}^{U L C}$ & $-2.279[1]$ & $-7.685 * * *[0]$ & -1.6470 & -1.7732 \\
\hline \multirow{7}{*}{ France } & $d d_{t}$ & $-1.692[2]$ & $-2.659 * * *[1]$ & -0.9772 & -1.0018 \\
\hline & $x_{t}$ & $-1.160[1]$ & $-4.640 * * *[1]$ & -1.0702 & -1.1443 \\
\hline & $x_{t}^{\text {goods }}$ & $-2.297[1]$ & $-7.339 * * *[0]$ & -1.2483 & -1.3156 \\
\hline & $x_{t}^{v a}$ & $-1.509[8]$ & $-1.842 *[7]$ & -0.7760 & -0.8076 \\
\hline & $y_{t}^{*}$ & $-3.268 *[1]$ & $-4.703 * * *[0]$ & -2.0007 & -2.0854 \\
\hline & $r_{t}$ & $-1.921[0]$ & $-10.654 * * *[0]$ & -2.6688 & -2.7981 \\
\hline & $r_{t}^{U L C}$ & $-3.129 *[1]$ & $-8.750^{* * *}[0]$ & -1.5954 & -1.6572 \\
\hline \multirow{7}{*}{ Ireland } & $d d_{t}$ & $-1.650[3]$ & $-2.805^{* * *}[2]$ & -0.6024 & -0.6188 \\
\hline & $x_{t}$ & $-0.764[4]$ & $-1.401[6]$ & -1.1048 & -1.1648 \\
\hline & $x_{t}^{\text {goods }}$ & $-1.273[4]$ & $-4.099 * * *[3]$ & -1.3362 & -1.4306 \\
\hline & $x_{t}^{v a}$ & $-2.308[8]$ & $-2.059 * *[7]$ & -0.5018 & -0.5126 \\
\hline & $y_{t}^{*}$ & $-2.580[2]$ & $-5.141 * * *[1]$ & -1.8182 & -1.9890 \\
\hline & $r_{t}$ & $-1.837[0]$ & $-9.162 * * *[0]$ & -1.8346 & -1.9568 \\
\hline & $r_{t}^{U L C}$ & $-1.896[1]$ & $-7.549 * * *[0]$ & -1.2778 & -1.3429 \\
\hline \multirow{7}{*}{ Greece } & $d d_{t}$ & $-0.109[5]$ & $-2.906 * * *[4]$ & -1.1719 & -1.2182 \\
\hline & $x_{t}$ & $-1.734[4]$ & $-5.125 * * *[3]$ & -2.4917 & -2.8454 \\
\hline & $x_{t}^{\text {goods }}$ & $-3.015[4]$ & $-5.130 * * *[3]$ & $-4.1321 * *$ & $-4.8821 * * *$ \\
\hline & $x_{t}^{v a}$ & $-1.232[8]$ & $-1.271[6]$ & -0.8985 & -0.9393 \\
\hline & $y_{t}^{*}$ & $-3.646^{* *}[1]$ & $-4.249 * * *[0]$ & -1.8027 & -1.9790 \\
\hline & $r_{t}$ & $-0.810[0]$ & $-12.329 * * *[0]$ & $-3.5230^{*}$ & $-3.8786^{* *}$ \\
\hline & $r_{t}^{U L C}$ & $-2.029[1]$ & $-9.804 * * *[0]$ & -1.9257 & -2.0192 \\
\hline
\end{tabular}

ADF test: lag length is chosen by minimizing the Schwarz Information Criterion with a prior defined maximum lag length of 12 . Critical values for an intercept: $1 \%:-3.43,5 \%:-2.86,10 \%:-2.57$. Critical values for both an intercept and a time trend: $1 \%:-3.96,5 \%:-3.41,10 \%:-3.13$. Critical values without deterministic trends (for first differences): $1 \%:-2.56,5 \%:-1.94,10 \%:-1.62$.

Lee-Strazicich test: critical values with one break: $1 \%:-4.239,5 \%:-3.566,10 \%:-3.211$. Critical values with two breaks: $1 \%:-4.545,5 \%:-3.842,10 \%:-$ 3.504. Cf. Lee and Strazicich (2004) and Lee and Strazicich (2003). 
Table A3: Estimation results

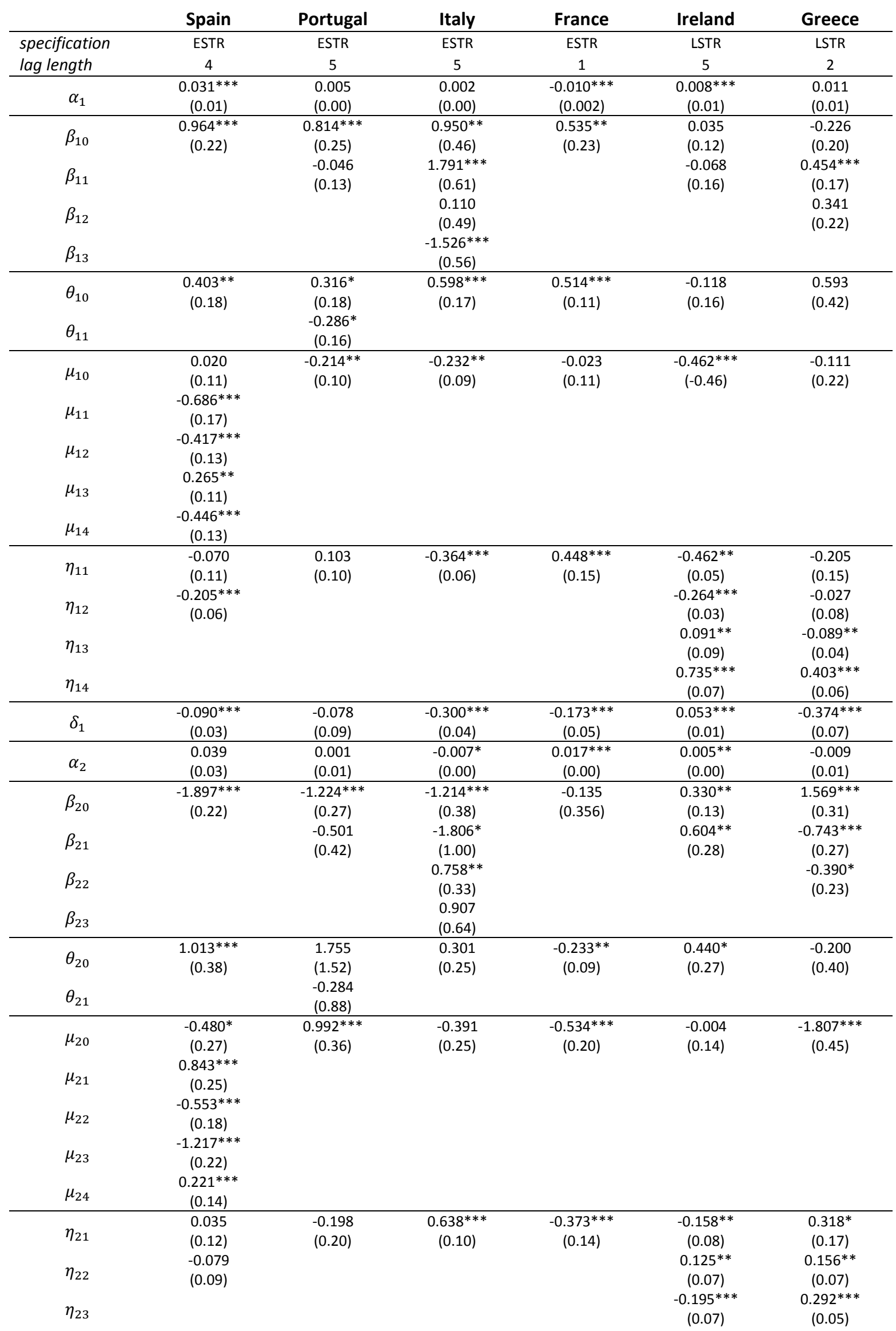




\begin{tabular}{|c|c|c|c|c|c|c|}
\hline$\eta_{24}$ & & & & & $\begin{array}{c}-0.433^{* * *} \\
(0.09) \\
\end{array}$ & $\begin{array}{r}-0.170 \\
(0.19) \\
\end{array}$ \\
\hline \multirow[b]{2}{*}{$\delta_{2}$} & -0.224 & 0.029 & 0.110 & $-0.168^{* * *}$ & $-0.155^{* * *}$ & 0.025 \\
\hline & $(0.16)$ & $(0.03)$ & $(0.08)$ & $(0.06)$ & $(0.034)$ & $(0.13)$ \\
\hline \multirow[b]{2}{*}{$\gamma$} & $35.566^{*}$ & 12.907 & $59.061 * * *$ & $1.638 * *$ & $3.842^{*}$ & $6.662 * * *$ \\
\hline & $(18.61)$ & $(13.46)$ & $(20.89)$ & $(0.68)$ & $(2.20)$ & $(2.29)$ \\
\hline $\mathrm{R}^{2}$ & 0.773 & 0.487 & 0.603 & 0.568 & 0.688 & 0.686 \\
\hline$p$-value BG test & 0.506 & 0.592 & 0.741 & 0.110 & 0.1044 & 0.714 \\
\hline
\end{tabular}

Coefficients estimated by NLS; Newey-West standard errors in parentheses. */**/*** statistical significance at the $10 \% / 5 \% / 1 \%$ level. The BreuschGodfrey Lagrange Multiplier (BG) test is based on the null hypothesis of no serial correlation of the residuals of order $p$. Due to quarterly data, we report the results for this test for $p=4$.

Table A4: Estimation with value added exports

\begin{tabular}{|c|c|c|c|c|c|c|}
\hline & Spain & Portugal & Italy & France & Ireland & Greece \\
\hline specification & ESTR & ESTR & LSTR & ESTR & ESTR & LSTR \\
\hline lag length & 6 & 6 & 6 & 3 & 2 & 2 \\
\hline$\beta_{10}$ & $\begin{array}{c}0.193^{* * * *} \\
(0.01)\end{array}$ & $\begin{array}{l}0.027 \\
(0.02) \\
\end{array}$ & $\begin{array}{c}-0.372 * * \\
(0.19) \\
\end{array}$ & $\begin{array}{c}-0.023 \\
(0.08) \\
\end{array}$ & $\begin{array}{c}-0.068 * * * \\
(0.00)\end{array}$ & $\begin{array}{c}0.024^{* * *} \\
(0.01)\end{array}$ \\
\hline$\beta_{20}$ & $\begin{array}{c}-0.293 * * * \\
(0.05)\end{array}$ & $\begin{array}{c}-0.046 \\
(0.03)\end{array}$ & $\begin{array}{c}0.807^{* *} \\
(0.38)\end{array}$ & $\begin{array}{c}0.459 * * * \\
(0.16)\end{array}$ & $\begin{array}{c}0.061^{* * *} \\
(0.00)\end{array}$ & $\begin{array}{c}-0.055^{* * *} \\
(0.01)\end{array}$ \\
\hline$\beta_{10}+\beta_{20}$ & $\begin{array}{c}-0.100 * * \\
{[0.04]}\end{array}$ & $\begin{array}{c}-0.019 \\
{[0.61]}\end{array}$ & $\begin{array}{c}0.435^{*} \\
{[0.09]}\end{array}$ & $\begin{array}{c}0.436 * * * \\
{[0.00]}\end{array}$ & $\begin{array}{c}-0.006^{*} \\
{[0.08]}\end{array}$ & $\begin{array}{c}-0.031 * * * \\
{[0.00]}\end{array}$ \\
\hline$\beta_{11}$ & - & $\begin{array}{r}-0.012 \\
(-0.01) \\
\end{array}$ & $\begin{array}{c}-0.724 * * * \\
(0.22)\end{array}$ & - & $\begin{array}{c}-0.040 * * * \\
(0.00)\end{array}$ & $\begin{array}{c}0.035^{* * *} \\
(0.01)\end{array}$ \\
\hline$\beta_{21}$ & - & $\begin{array}{c}0.399 * * * \\
(0.14)\end{array}$ & $\begin{array}{c}0.590 * * \\
(0.27)\end{array}$ & - & $\begin{array}{c}0.028^{* * * *} \\
(0.00)\end{array}$ & $\begin{array}{c}-0.028^{* *} \\
(0.01) \\
\end{array}$ \\
\hline$\beta_{11}+\beta_{21}$ & - & $\begin{array}{c}0.388 * * * \\
{[0.00]}\end{array}$ & $\begin{array}{c}-0.134^{* *} \\
{[0.02]}\end{array}$ & - & $\begin{array}{c}-0.012 * \\
{[0.08]}\end{array}$ & $\begin{array}{c}0.007 * * * \\
{[0.00]}\end{array}$ \\
\hline$\gamma$ & $\begin{array}{c}17.346 \\
(4.35)\end{array}$ & $\begin{array}{c}11.611 \\
(4.15)\end{array}$ & $\begin{array}{l}3.455 \\
(1.31) \\
\end{array}$ & $\begin{array}{l}0.687 \\
(0.13) \\
\end{array}$ & $\begin{array}{l}1.409 \\
(0.11) \\
\end{array}$ & $\begin{array}{c}3.456 \\
(0.42) \\
\end{array}$ \\
\hline$R^{2}$ & 0.996 & 0.948 & 0.937 & 0.919 & 0.999 & 0.996 \\
\hline $\begin{array}{l}\text { p-value } \\
\text { BG test }\end{array}$ & 0.437 & 0.006 & 0.000 & 0.000 & 0.036 & 0.113 \\
\hline
\end{tabular}

Coefficients estimated by NLS; Newey-West standard errors in parentheses. ${ }^{*} / * * * * *$ statistical significance at the $10 \% / 5 \% / 1 \%$ level. For the joint significance of the coefficients $\beta_{1 i}$ and $\beta_{2 i}$, the linear restriction $\beta_{1 i}+\beta_{2 i}=0$ has been tested with Chi-squared test statistics; $\mathrm{p}$-value in brackets. The Breusch-Godfrey Lagrange Multiplier (BG) test is based on the null hypothesis of no serial correlation of the residuals of order $p=4$. Full results are available from the authors upon request. 
Table A5: Estimation without long-run adjustment coefficient

\begin{tabular}{|c|c|c|c|c|c|c|}
\hline & Spain & Portugal & Italy & France & Ireland & Greece \\
\hline specification & ESTR & ESTR & ESTR & ESTR & LSTR & LSTR \\
\hline lag length & 4 & 6 & 5 & 1 & 3 & 2 \\
\hline$\beta_{10}$ & $\begin{array}{c}0.671^{* * *} \\
(0.19)\end{array}$ & $\begin{array}{c}0.762 * * * \\
(0.12)\end{array}$ & $\begin{array}{l}0.213 \\
(0.68) \\
\end{array}$ & $\begin{array}{c}0.714^{* * *} \\
(0.26)\end{array}$ & $\begin{array}{c}-0.062 \\
(0.24) \\
\end{array}$ & $\begin{array}{c}-0.365^{*} \\
(0.20)\end{array}$ \\
\hline$\beta_{20}$ & $\begin{array}{c}-1.205^{* * *} \\
(0.18)\end{array}$ & $\begin{array}{c}-1.034^{* * *} \\
(0.17)\end{array}$ & $\begin{array}{c}-0.209 \\
(0.55)\end{array}$ & $\begin{array}{c}0.039 \\
(0.54)\end{array}$ & $\begin{array}{c}0.464 \\
(0.31)\end{array}$ & $\begin{array}{c}2.036 * * * \\
(0.34)\end{array}$ \\
\hline$\beta_{10}+\beta_{20}$ & $\begin{array}{c}-0.534^{*} \\
{[0.05]}\end{array}$ & $\begin{array}{c}-0.271 * * * \\
{[0.00]}\end{array}$ & $\begin{array}{l}0.004 \\
{[0.99]}\end{array}$ & $\begin{array}{c}0.754^{* *} \\
{[0.01]}\end{array}$ & $\begin{array}{c}0.403 * * * \\
{[0.00]}\end{array}$ & $\begin{array}{c}1.671 * * * \\
{[0.00]}\end{array}$ \\
\hline$\beta_{11}$ & - & $\begin{array}{c}0.364^{* * *} \\
(0.08)\end{array}$ & $\begin{array}{c}1.276^{*} \\
(0.65)\end{array}$ & - & $\begin{array}{c}-0.118 \\
(0.29)\end{array}$ & $\begin{array}{c}0.527^{* *} \\
(0.21)\end{array}$ \\
\hline$\beta_{21}$ & - & $\begin{array}{c}-1.126^{* * *} \\
(0.11)\end{array}$ & $\begin{array}{c}-0.980 \\
(0.84) \\
\end{array}$ & - & $\begin{array}{c}0.745 \\
(0.47)\end{array}$ & $\begin{array}{c}-0.795 \\
(0.52) \\
\end{array}$ \\
\hline$\beta_{11}+\beta_{21}$ & - & $\begin{array}{c}-0.762 * * * \\
{[0.00]}\end{array}$ & $\begin{array}{l}0.295 \\
{[0.29]}\end{array}$ & - & $\begin{array}{c}0.627 * * * \\
{[0.00]}\end{array}$ & $\begin{array}{c}-0.269 \\
{[0.00]}\end{array}$ \\
\hline$\gamma$ & $\begin{array}{c}24.507 \\
(23.95)\end{array}$ & $\begin{array}{c}38.141^{* *} \\
(17.69)\end{array}$ & $\begin{array}{c}96.197 * * * \\
(13.60)\end{array}$ & $\begin{array}{c}1.362^{*} \\
(0.72)\end{array}$ & $\begin{array}{c}1.032^{* * *} \\
(0.00)\end{array}$ & $\begin{array}{c}4.064^{* * * *} \\
(1.52)\end{array}$ \\
\hline $\mathrm{R}^{2}$ & 0.751 & 0.547 & 0.504 & 0.358 & 0.667 & 0.626 \\
\hline $\begin{array}{l}\mathrm{p} \text {-value } \\
\text { BG test }\end{array}$ & 0.638 & 0.735 & 0.164 & 0.101 & 0.058 & 0.934 \\
\hline
\end{tabular}

Coefficients estimated by NLS; Newey-West standard errors in parentheses. */**/*** statistical significance at the $10 \% / 5 \% / 1 \%$ level. For the joint significance of the coefficients $\beta_{1 i}$ and $\beta_{2 i}$, the linear restriction $\beta_{1 i}+\beta_{2 i}=0$ has been tested with Chi-squared test statistics; $\mathrm{p}$-value in brackets. The Breusch-Godfrey Lagrange Multiplier (BG) test is based on the null hypothesis of no serial correlation of the residuals of order $p=4$. Full results are available from the authors upon request. 


\section{References}

Ahn, J., and A.F. McQuoid (2013): Capacity Constrained Exporters: Micro Evidence and Macro Implications. Department of Economics Working Papers 1301, Florida International University.

Artus, J. R. (1970): The Short-term Effects of Domestic Demand Pressure on British Exports Performance. International Monetary Fund Staff Papers 17, pp. 247-274.

Artus, J. R. (1973): The Short-Run Effects on Domestic Demand Pressure on Export Delivery Delays for Machinery. Journal of International Economics 3, pp. 21-36.

Bai, J., and P. Perron (2003): Computation and Analysis of Multiple Structural Change Models. Journal of Applied Econometrics 18, pp. 1-22.

Baldwin R. and P. Krugman (1989): Persistent Trade Effects of Large Exchange Rate Shocks. Quarterly Journal of Economics 104(4), pp.635-54.

Ball, R. J. (1961): Credit restriction and the supply of exports. The Manchester School XXIX, pp. 161-172.

Ball, R. J., Eaton, J. R. and Steuer, M. D. (1966): The Relationship between United Kingdom Export Performance in Manufactures and the Internal Pressure of Demand. Economic Journal 76, pp. 501-518.

Belke, A., A. Oeking and R. Setzer (2014): Domestic demand, capacity constraints and exporting dynamics: Empirical evidence for vulnerable euro area countries. Economic Modelling, forthcoming.

Belke, A., and M. Goecke (2005): Real Options Effects on Employment: Does Exchange Rate Uncertainty Matter for Aggregation? German Economic Review 6, pp. 185-203.

Belke, A., M. Goecke and M. Guenther (2013): Exchange Rate Bands of Inaction and Play-Hysteresis in German Exports - Sectoral Evidence for Some OECD Destinations. Metroeconomica 64, pp. 152-179.

Berman, N., A. Berthou, and J. Héricourt (2011): Export Dynamics and Sales at Home. CEPR Discussion Paper No. 8684, Centre for Economic Policy Research, London.

Blum, B., Claro, S. and I. Horstmann (2011): Occasional vs Perennial Exporters: The Impact of Capacity on Export Mode, mimeo.

Christodoulopoulou, Styliani and Olegs Tkacevs (2014): Measuring the effectiveness of cost and price competitiveness in external rebalancing of euro area countries: What do alternative $\mathrm{HCls}$ tell us? ECB Working Paper Series No. 1736, Frankfurt.

Dunlevy, J.A. (1980): A Test of the Capacity Pressure Hypothesis within a Simultaneous Equations Model of Export Performance. Review of Economics and Statistics 62(1), pp. 131-135. 
ECB (2013): Country Adjustment in the Euro Area. Monthly Bulletin, May, European Central Bank, Frankfurt/Main.

Escribano, A. and O. Jordá (1999): Improved testing and specification of smooth transition regression models. In: P. Rothman (ed.): Non-linear Time Series Analysis of Economic and Financial data. Boston: Kluwer, pp. 289-319.

Esteves, P.S., and A. Rua (2013): Is There a Role for Domestic Demand Pressure on Export Performance? ECB Working Paper Series No. 1594, Frankfurt.

European Commission (2011): Export Demand Equations for Euro Area Countries. Quarterly Report on the Euro Area, Box IV.1, European Central Bank, Frankfurt/Main.

Faini, R. (1994): Export supply, capacity and relative prices. Journal of Development Economics 45(1), pp. 81100.

Gregory, A. W. and B. E. Hansen (1996a): Residual-based Tests for Cointegration in Models with Regime Shifts. Journal of Econometrics 70(1), pp. 99-126.

Gregory, A. W. and B. E. Hansen (1996b): Tests for Cointegration in Models with Regime and Trend Shifts. Oxford Bulletin of Economics and Statistics 58(3), pp. 555-560.

Ilmakunnas, P., and S. Nurmi (2007): Dynamics of Export Market Entry and Exit. Helsinki Institute of Economic Research Discussion Paper 197, Helsinki, November.

Lee, J., and M.C. Strazicich (2003): Minimum LM Unit Root Test with Two Structural Breaks. Review of Economics and Statistics 85(4), 1082-1089.

Lee, J., and M.C. Strazicich (2004): Minimum LM Unit Root Test with One Structural Break. Appalachian State University Working Paper.

MacKinnon, J. (1991): Critical Values for Cointegration Tests. In: R.F. Engle and C.W.J. Granger (eds): LongRun Economic Relationships. London, Oxford, 1991, pp 267-276.

Máñez, J.A., Rochina, M.E., and J.A. Sanchis Llopis (2008): Sunk Cost Hysteresis in Spanish Manufacturing Exports. Review of World Economics 144, pp. 272-294.

Sharma, K. (2003): Factors Determining India's Export Performance. Journal of Asian Economics 14, pp. 435446.

Smyth, D. J. (1968): Stop-Go and United Kingdom Exports of Manufactures. Oxford Bulletin of Economics and Statistics 30, pp. 25-36.

Soderbery, A. (2011): Market Size, Structure, and Access: Trade with Capacity Constraints, mimeo. 
Teräsvirta, T. (1994): Specification, Estimation and Evaluation of Smooth Transition Autoregressive Models. Journal of the American Statistical Association, 89 (425), 208-218.

Teräsvirta, T. (1998): Modelling Economic Relationships with Smooth Transition Regressions. Giles, D.E.A., Ullah, A. (eds), Handbook of Applied Economic Statistics. New York: Marcel Dekker, 507-552.

Vannoorenberghe, G. (2012): Firm-level Volatility and Exports. Journal of International Economics 86, pp. 5767.

Zilberfarb, B.-Z. (1980): Domestic Demand Pressure, Relative Prices and the Exports Supply Equation-More Empirical Evidence. Economica 47, pp. 443-450. 